\title{
Late Pliocene Paleoecologic Reconstructions Based on Ostracode Assemblages from the Sagavanirktok and Gubik Formations, Alaskan North Slope
}

\author{
ELISABETH M. BROUWERS ${ }^{1}$
}

(Received 27 January 1992; accepted in revised form 12 May 1993)

\begin{abstract}
Shallow-marine ostracode assemblages from upper Pliocene sediments of the upper part of the Sagavanirktok Formation and lower part of the Gubik Formation record the last warm period that occurred before the onset of significant cooling of the Arctic Ocean and the initiation of Northern Hemisphere continental glaciation. The informally named Colvillian and Bigbendian transgressions represent the oldest deposits of the Gubik Formation and are dated, based on various lines of evidence, between 2.48 and $3 \mathrm{Ma}$. Ostracode faunas from the lower part of the Gubik Formation indicate a cold-temperate to subfrigid marine climate with summer bottom temperatures $1-4^{\circ} \mathrm{C}$ warmer than today. Deposits of the upper part of the Sagavanirktok Formation at Manning Point and Barter Island are older than Colvillian sediments but are believed to be late Pliocene in age and contain an ostracode fauna that has many species in common with the lower part of the Gubik Formation. The Sagavanirktok ostracode faunas indicate a cold-temperate to subfrigid marine climate, similar to that inferred for the lower part of the Gubik Formation, with summer bottom temperatures $1-3^{\circ} \mathrm{C}$ warmer than today.

The opening of Bering Strait at about $3 \mathrm{Ma}$ altered Arctic Ocean assemblage composition as Pacific species migrated into the Arctic and North Atlantic oceans. The admixture of evolutionarily distinct faunas from the Atlantic and Pacific oceans identifies Colvillian (and younger) faunas and provides a convenient reference horizon in the Alaskan fossil record. The marine climatic deterioration that followed the Bigbendian appears to have been abrupt and is documented by biotic turnover, with large numbers of species extinctions and first appearances of new species. The change in species composition can be attributed to the cooling of the Arctic Ocean during the late Pliocene.

Key words: Pliocene, ostracode, Sagavanirktok Formation, Nuwok Member, Gubik Formation, Alaska, North Slope, shallow marine

RÉSUMÉ. Des assemblages d'ostracodes de milieu marin peu profond trouvés dans des sédiments datant du pliocène supérieur et situés dans la couche supérieure de la formation de Sagavanirktok et dans la couche inférieure de la formation de Gubik témoignent de la dernière période tempérée qui a précédé le refroidissement majeur de l'océan Arctique et la glaciation continentale de l'hémisphère boréal. Les transgressions communément appelées colvillienne et bigbendienne représentent les plus anciens dépôts de la formation de Gubik et on les fait remonter, en s'appuyant sur des preuves diverses, à une période située entre 2,48 et $3 \mathrm{Ma}$. Les faunes d'ostracodes situées dans la couche inférieure de la formation de Gubik témoignent d'un climat marin allant de froid-tempéré à glacial, avec des températures estivales au fond de 1 à $4^{\circ} \mathrm{C}$ plus élevées que de nos jours. Les dépôts de la couche supérieure de la formation de Sagavanirktok à Manning Point et à Barter Island sont plus anciens que les sédiments colvilliens, mais dateraient du pliocène tardif et renferment une faune d'ostracodes partageant un grand nombre d'espèces avec la couche inférieure de la formation de Gubik. Les faunes d'ostracodes de Sagavanirktok témoignent d'un climat marin, allant de froid-tempéré à glacial, semblable à celui qui aurait pu exister au moment où commença à se déposer la formation de Gubik, avec des températures estivales au fond de 1 à $3{ }^{\circ} \mathrm{C}$ plus élevées que de nos jours.

L'ouverture du détroit de Béring il y a environ $3 \mathrm{Ma}$ a changé la composition des assemblages de l'océan Arctique avec la migration dans les océans Arctique et Atlantique Nord d'espèces venant du Pacifique. Le mélange de faunes distinctes sur le plan de l'évolution venant de l'Atlantique et du Pacifique identifie les faunes colvilliennes (et plus récentes) et offre un horizon repère pratique pour le dossier fossile de l'Alaska. Le refroidissement climatique marin qui a suivi l'époque bigbendienne semble avoir été soudain et est confirmé par le renouvellement biotique, avec la disparition d'un grand nombre d'espèces et l'apparition de nouvelles. On peut attribuer le changement dans la variété des espèces au refroidissement de l'océan Arctique durant le pliocène tardif.
\end{abstract}

Mots clés: pliocène, ostracode, formation de Sagavanirktok, membre de Nuwok, formation de Gubik, Alaska, versant Nord, milieu marin peu profond

Traduit pour le Journal par Nésida Loyer.

\section{INTRODUCTION}

Upper Pliocene marine sediments throughout the Northern Hemisphere provide evidence of oceanographic and climatic changes that impacted the Arctic Basin, including 1) changes in North Atlantic circulation between 3 and 5 Ma caused by the final closure of the Isthmus of Panama and the consequent strengthening of the Gulf Stream (Keigwin, 1978; Jones and Hasson, 1985; Hodell et al., 1985), 2) the opening of Bering Strait about 3-4 Ma (Gladenkov, 1981; Einarsson and Albertsson, 1988; Gladenkov et al., 1991), allowing the first exchange of Pacific faunas and water masses since the Late Cretaceous (Marincovich et al., 1990), 3) progressive cooling of the Arctic Ocean beginning about $4 \mathrm{Ma}$ (Herman and Hopkins, 1980; Clark, 1990), and 4) the first significant development of North Atlantic sea ice at about $2.4 \mathrm{Ma}$, as evidenced by greatly increased ice rafting and iceberg delivery to lower latitudes (Shackleton et al., 1984; Raymo et al.,
1989; Jansen and Sjoholm, 1991; Sikes et al., 1991) and the development of Northern Hemisphere ice sheets. The effects of these climatic and oceanographic changes can be seen in Arctic Ocean shallow-water faunas and include the first appearance of North Pacific forms in the Arctic and North Atlantic beginning about 3 Ma (Durham and MacNeil, 1967; Gladenkov, 1981; Gladenkov et al., 1980; Fyles et al., 1991) and the first development of cold-water arctic taxa between 2.7 and 2.4 Ma (Repenning et al., 1987; Repenning and Brouwers, 1992), including forms tolerant to sea ice conditions.

The upper part of the Sagavanirktok Formation and the lower part of the Gubik Formation of the Alaskan arctic coastal plain contain a shallow-marine record of late Pliocene climatic and oceanographic changes at high northern latitudes. This paper examines a distinctive assemblage of ostracode species from sedimentary rocks of the uppermost

UU.S. Geological Survey, MS 919, Box 25046, Federal Center, Denver, Colorado 80225, U.S.A.

(C)The Arctic Institute of North America 
Sagavanirktok Formation at Manning Point and Barter Island and from the lower part of the Gubik Formation, both of which crop out on the eastern coastal plain of the Alaskan North Slope. The goals are to document the ostracode assemblages of each unit, to reconstruct paleoenvironments, and to estimate bottom-water temperatures of late Pliocene high-sea-level events of arctic Alaska.

\section{GEOLOGIC SETTING}

Tertiary rocks crop out northward from the Brooks Range to the Arctic Ocean (Fig. 1), extending into the continental shelf beneath the Beaufort Sea (Grantz et al., 1982, 1990). Bedrock exposures of pre-Quaternary sediments are sparse in the foothills and coastal plain of the North Slope of Alaska, with a few exceptions where streams have incised the tundra cover and exposed older sediments. In northeastern Alaska, post-Cretaceous sediments have been placed into the Tertiary Sagavanirktok Formation (Detterman et al., 1975; Fig. 1) and the Pliocene and Quaternary Gubik Formation (Dinter et al., 1990).

Figure 2 shows the location of the streams and coastal bluffs on the eastern coastal plain of the Alaskan North Slope where fossiliferous shallow-marine strata of the Sagavanirktok Formation and the basal Gubik Formation studied here have been collected.

\section{Sagavanirktok Formation}

The Sagavanirktok Formation includes three members that crop out as three type exposures (Detterman et al., 1975; Fig. 1): 1) the oldest Sagwon Member, 2) the Franklin Bluffs Member, and 3) the youngest Nuwok Member. The Sagwon and Franklin Bluffs members are nonmarine deposits that are mostly Paleogene in age (Ager et al., 1985; J.A. Barron, written comm., 1976); the Nuwok Member represents the only marine sediments in the Sagavanirktok Formation.

The type locality of the Nuwok Member is along the northern part of Carter Creek, about $160 \mathrm{~km}$ east of Prudhoe Bay and about $2.3 \mathrm{~km}$ south of the Beaufort Sea (Fig. 2, locality 6). Fossiliferous shallow-marine strata of the Nuwok Member are found along streams and coastal bluffs in the Camden Bay area in the easternmost coastal plain of the Alaskan North Slope. At the type locality, the Nuwok Member is exposed along the north flank of the Marsh Creek anticline (Morris, 1957; Reiser et al., 1971; Lyle et al., 1980; Bird and Molenaar, 1987; Molenaar et al., 1987). Scattered exposures along the Marsh Creek anticline west of Carter Creek are believed to represent several tens of metres of strata that overlie the type section, and extensive exposures to the southeast of Carter Creek indicate that several hundred metres of strata underlie the type section (Fouch et al., 1990; Fouch et al., unpubl. field data, 1988).
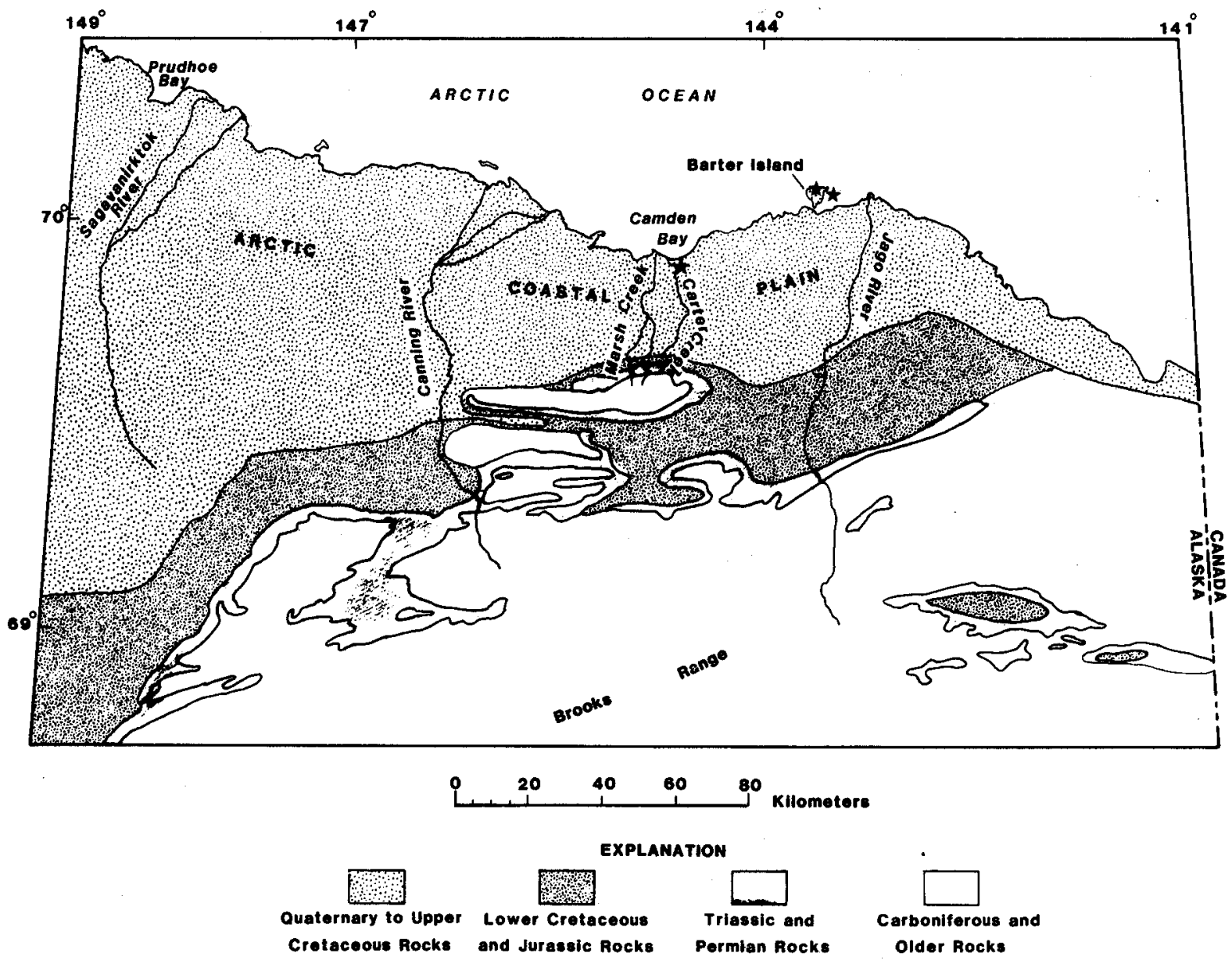

FIG. 1. Geologic map showing distribution of major units in northeast Alaska (adapted from Detterman et al., 1975). Solid dots indicate outcrops of the Sagavanirktok Formation. 


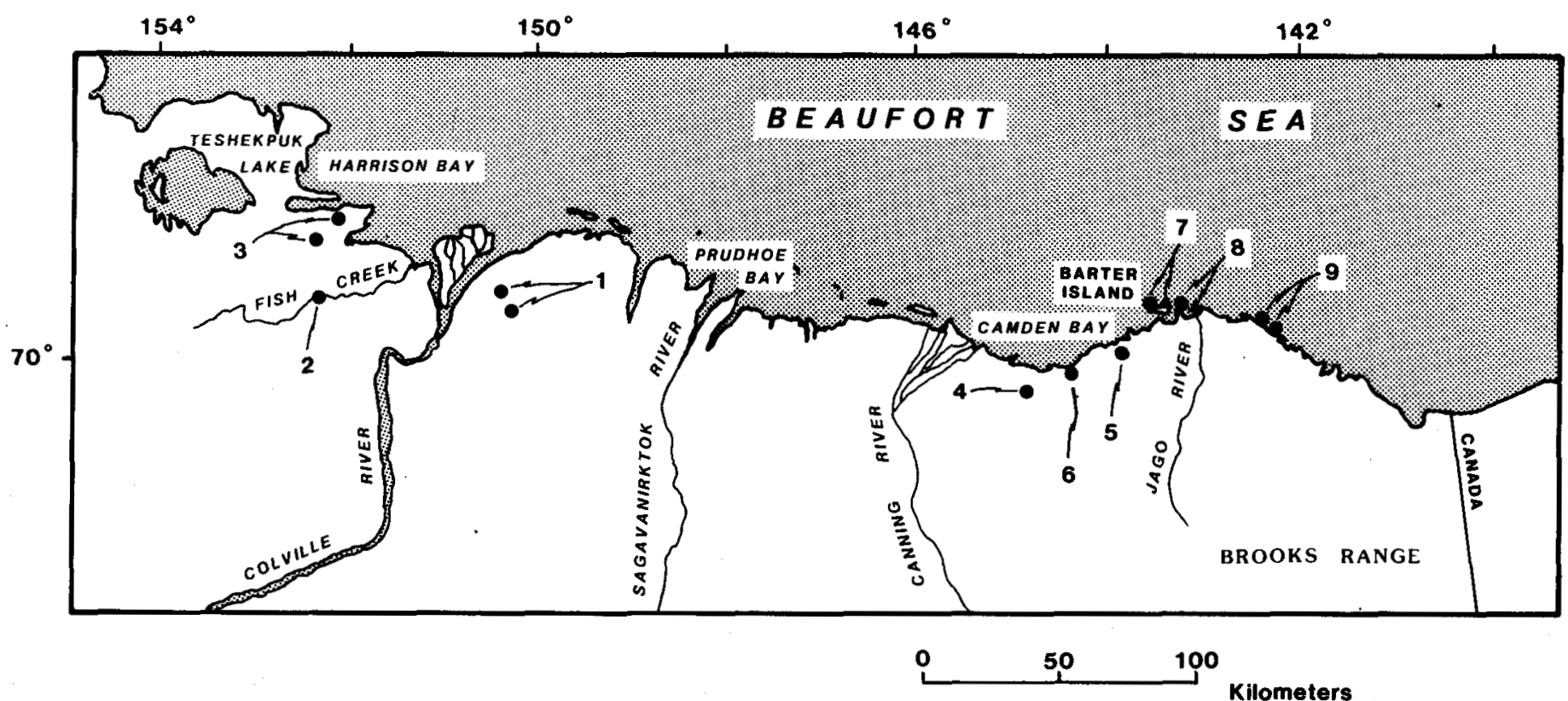

FIG. 2. Map of northeast Alaska showing localities of the upper part of the Sagavanirktok Formation and basal Gubik Formation (Colvillian and Bigbendian transgressions) discussed in this report (solid dots). 1) Miluveach River, 2) Fish Creek, 3) Kogru River, 4) Colville River, 5) North flank of Marsh anticline, 6) Carter Creek, 7) Barter Island, 8) Manning Point, 9) Pokok Lagoon.

At Manning Point and Barter Island, along the Beaufort Sea coast northeast of Carter Creek (Fig. 3), are two coastal localities with sediments that have been referred to the Nuwok Member (Brouwers and Marincovich, 1988; Marincovich et al., 1990). At the Manning Point locality, a coastal bluff of massive mudstone crops out along the eastern length of the island. A distinctive horizon containing concretions, concentrations of valves of the mollusk Thyasira alaskana, and large crystals of the mineral glendonite occurs in the middle of the exposure. This horizon is identical to one found at the type locality of the Nuwok Member, and the two horizons are inferred to be coeval (Brouwers and Marincovich, 1988). The ubiquitous presence of glendonite crystals has been used by field geologists to identify the Nuwok Member. Rare glendonite crystals have been found

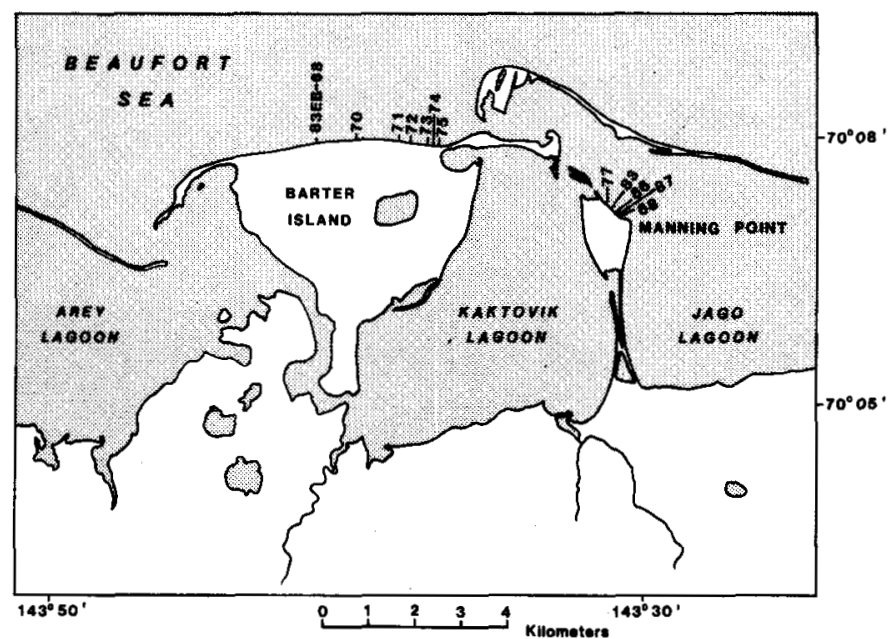

FIG. 3. Map showing location of samples collected from the Nuwok Member of the Sagavanirktok Formation at Barter Island and Manning Point. See Figure 2 for map location. in a few exposures of the Gubik Formation (e.g., at Fish Creek; C.A. Repenning, pers. comm. 1989), but an abundance of glendonite is diagnostic only of the Nuwok Member on the Alaskan North Slope. Microscopic glendonite crystals are found in the mudstones stratigraphically above the distinctive horizon at Manning Point as well as in mudstones on the north side of Barter Island, where the concretion-mollusk horizon does not occur.

Samples from the the upper part of the Nuwok Member at Manning Point, above the concretion and glendonite horizon (83-EB-86, 83-EB-87, 83-EB-88), and at Barter Island (83-EB-68, 83-EB-70, 83-EB-71) contain an ostracode assemblage of arctic affinity that differs from the Nuwok ostracode assemblage of the type locality at Carter Creek (Tables 1, 2). The Manning Point and Barter Island samples are believed to represent sediments intermediate in age between the uppermost Nuwok Member at the type locality and the oldest recognized Gubik Formation (the Colvillian transgression). The most diagnostic age delimiter of the Manning Point-Barter Island samples is the absence of Pacific-derived ostracode genera such as Palmenella, Robertsonites, Finmarchinella, and Cythere, indicating deposition prior to the opening of Bering Strait and hence a minimum age of about 3.2 Ma. Mollusk and ostracode species found in the youngest sediments at the type Nuwok at Carter Creek do not occur in the Manning Point-Barter Island assemblage (Brouwers and Marincovich, 1988; Fouch et al., 1990); I infer that the Manning Point-Barter Island sediments examined here are younger than the youngest Nuwok at Carter Creek. Some of the Manning Point-Barter Island (pre-Colvillian) species are extant but long-ranging, and the oldest occurrence previously reported is from Colvillian sediments (this includes species such as Acanthocythereis dunelmensis, Cytheropteron arcuatum, $C$. simplex, Heterocyprideis sorbyana, Krithe glacialis, Paracyprideis 
TABLE 1. Occurrence chart of ostracode species in samples of the Sagavanirktok and Gubik Formations ${ }^{1}$

\begin{tabular}{|c|c|c|c|c|c|c|c|c|c|c|c|c|c|c|c|c|c|c|c|}
\hline & & 兽 & & & & 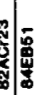 & & & 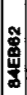 & \begin{tabular}{|c}
0 \\
0 \\
0 \\
0 \\
0
\end{tabular} & 愘 & 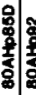 & 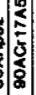 & $\mid$ & & & & & 总 \\
\hline Acanthocyther ols denotmanais & & 26 & 2 & 5 & 8 & \begin{tabular}{l|l}
3 & 7
\end{tabular} & 7 & & 2 & & \begin{tabular}{l|l}
11 \\
14
\end{tabular} & \begin{tabular}{l|l}
14 & 1 \\
1
\end{tabular} & & & & & & 2 & 3 \\
\hline Arglllobcia condidia & & & & & 3 & \begin{tabular}{c|c}
3 & 3 \\
\end{tabular} & & & & 4 & & & & & & & & & \\
\hline Arolloodia ep. A & & & & & & & & & & & & & & & & & $\sqrt{2}$ & & \\
\hline Arolloedia producta & & & & & & & 6 & & & & & & & & & & & & \\
\hline Bythocythere sp. A & & & & & 2 & & & & & & & & & & & & & & \\
\hline Curthis cluther & & & & & 5 & 4 & & & & & & & & & & & & & \\
\hline Cythere hutes & & & & & E & & & & & & & & & 3 & & & & & \\
\hline Cytherotts toenekpukeneis & & & & & & & & & & 2 & 31 & & & 2 & & & & & \\
\hline Cytheromorpha macchoenoyi & 2 & 1 & & & 2 & \begin{tabular}{l|l}
2 & 4 \\
\end{tabular} & & & & 4 & & & & 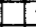 & 1 & & & & 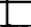 \\
\hline Cytheromorph kallikpikensile & 3 & & & & & 9 & 11 & 13 & & & & & & & & & & & \\
\hline Cytheromorph manningensis & & & & & 1 & 14 & & & & 1 & & & & 1 & & & & 3 & 2 \\
\hline Cytheropteron arcuatum & 3 & 6 & & & 2 & 24 & 1 & & & 4 & & 4 & & & & & & 1 & 4 \\
\hline Cytheropteron aff. C. ercuatum & & & & & & & & & & $T$ & & & & & & & & & 1 \\
\hline Cytheropteron biconvexum & & & & & & & & & & & & & & & & & & & 1 \\
\hline Cytheropteron dimilingtonensls & & 4 & & & & & 7 & 7 & 1 & 4 & 8 & & 5 & & & & & & \\
\hline Cytheroptoron deent & 5 & 4 & & & & & & & 1 & & & 1 & & & & & & & 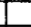 \\
\hline Cytheropteron intlatum & & & & & & 3 & \begin{tabular}{l|l}
3 & 1 \\
\end{tabular} & & & & & & & & & & & & \\
\hline Cytheropteron aff. c. latissimum & & 3 & & & & & & & & & & & & & & & & & \\
\hline Cytheropteron montroevienses & 1 & & & & & & & & & & & 1 & & & & & & & \\
\hline Cytheropteron persalatiseinum & 3 & & & & & & & & & & & 4 & & & & & & 1 & 7 \\
\hline Cythoropteron pseudomontrosiense & 1 & & & & & & & & & & & & & & & & & 1 & 1 \\
\hline Cytheropteron wodowl & & & & & & & 1 & & & & & & & & & & & & \\
\hline Cytheropteron simplex & 1 & & & & & 2 & 2 & & & & & E & & & & & & 8 & 11 \\
\hline Gytheropteron carterl & & 3 & & & 2 & & & & & & & & 1 & & & & & & 3 \\
\hline Cytheropteron sp. B & & & & & & & & & & & & 1 & 3 & & & & & & \\
\hline Cytheropteron ap. C & & & & & & & & & & & & & & & 1 & & & & \\
\hline Cytheropteron sp. D & & & & & & & & & & & & & 1 & & & & & & \\
\hline Cytheropteron ep. & & & & & & & & & & & & & & & 1 & & & & \\
\hline Eloteonia ap. & & & & & 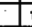 & 1 & & & & & & & 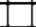 & & & & & & \\
\hline Eoteonalla concinine & 27 & 33 & 28 & 1 & & 8 & 10 & & & & & 2 & & & & & & & \\
\hline Eucythere ergis & & & & & & $5 \longdiv { 2 }$ & 3 & & & 1 & & \begin{tabular}{l|l}
2 & 1 \\
\end{tabular} & 1 & & & & & & \\
\hline Frmmerchinelle loganl & & & & 1 & & & & & & & & & 3 & & & & & & \\
\hline Henicythere villose & & & & & & & & & & & & & +6 & 3 & & & & & \\
\hline Heterocyortdele fascis & & 1118 & & 14 & 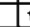 & 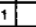 & & & & & & 3 & & & & & & & \\
\hline Haterocyprideles acotyanta & 12 & 28 & 3 & if & 1 t & 5 . 13 & 38 & 1 & & & $6 \mid 32$ & 38 & & & 1 & & & 2 & 2 \\
\hline Howning colvillenala & & & & & & & & & & & & & 22 & & & & & & \\
\hline Jonedia cinolox & & & & 1 & {$[3$} & $3 \sqrt{2}$ & & & & & & & & & & & & & \\
\hline Kritho declels & 9 & & 4 & & & & & & & 3 & & 726 & & & & 2 & 1. & 8 & 18 \\
\hline Loxooonche venepldermolides & & & & & & 1 & & & & 1 & & & & 3 & & & & & \\
\hline Mrneoyolia an A & & & & 2 & & & & & & & & & & & & & & & \\
\hline Penmenation lunicole & & 2 & 1 & & $B$ & 8 & 10 & 2 & & & & 8 & & & & & & & \\
\hline Polmoconcha sp. & 3 & 1 & 2 & & 2 & 2 & & & & & & & & & & & & & \\
\hline Perecypridele peesudopunctillata & 36 & 28 & 7 & 5 & 3 & & & 20 & 8 & & 121 & 1 & & & & 2 & 9 & & 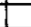 \\
\hline Precypordide aff. P. peroudopunet thate & & & & & & 1318 & 90 & 0 & & & & & & & & & & & \\
\hline Peredoxoetome sa & & & & & & & & 1 & & 2 & & & & 1 & & & & & \\
\hline Pteroloxh vemancta & 3 & & & & & & & & & & & & & & & & & & \\
\hline 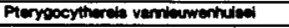 & 11 & 10 & 3 & & I & 17 & 15 & & & & $4 \sqrt{2}$ & 200 & & & & 1 & & & \\
\hline Pabimis perentrabuse & & 20 & & 10 & \pm 3 & 310 & 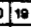 & 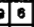 & 7 & & $37 \sqrt{6}$ & $\infty$ & & 3 & & & & & 10 \\
\hline 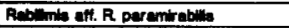 & & & & & & & & & & & & & & & & & 4 & & \\
\hline Rebillinis co. & & & & & & & & & & & & & 1 & & & & & & \\
\hline 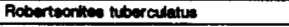 & 20 & 18 & - & 1 & 1.4 & 46 & 5 & & 1 & & 2227 & 27 & & & & & & & \\
\hline Fondetionin dobuliliere & & & & & & & & & & & & & & & & & & & 1 \\
\hline Microcytherura aff. M. expenda & & & & & & & & & & & & & 1 & & & & & & 1 \\
\hline 8erdoythalden bradil & 14 & 2 & & & & & & 3 & 8 & & & 7 & 11 & 3 & & & & & \\
\hline Seralcytheridien mecroleminata & 22 & 57 & 15 & 7 & 10 & $2 \sqrt{2}$ & 3 & 8 & 1 & 4 & & \begin{tabular}{l|l}
7 & 6 \\
\end{tabular} & 1 & 3 & & & & 2 & \\
\hline Serdeytheridea punetilate & & $\infty$ & & 13 & 2 & & & 2 & & & & & & & & & & & \\
\hline Serdeytherdidon an A & & & & & & & & & & & & 1 & & & & & & & 1 \\
\hline Serricytherure concenticica & 1 & & & & 2 & & 2 & 3 & & & & & & & & & & & \\
\hline Somicythenre compiennta & 1 & & & & & 3 & 3 & & & & & & & & & & & & 1 \\
\hline 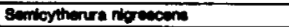 & & & & & & & & & & & & & 11 & & & & & & \\
\hline
\end{tabular}

${ }^{1}$ Counts refer to number of valves; adults and juveniles are combined. Based on the extent of amino acid racemization in associated mollusk shells of Hiatella arctica, samples $83 \mathrm{ACr} 56,90 \mathrm{ACr} 17,90 \mathrm{ACr} 19 \mathrm{~A}$, and $90 \mathrm{ACr} 19 \mathrm{C}$ are from Colvillian deposits; sample $82 \mathrm{ACr} 23$ is from Bigbendian deposits; sample $81 \mathrm{ACr} 6$ is from Bigbendian or Fishcreekian deposits; and sample $85 \mathrm{ACr} 120$ is from Fishcreekian deposits (L.D. Carter, written comm. 1991).

pseudopunctillata, Roundstonia globulifera, Sarsicytheridea macrolaminata, Semicytherura complanata; Table 2).

The pre-Colvillian assemblage from the Nuwok Member of the Sagavanirktok Formation at Manning Point and Barter Island can be no younger than the opening of Bering Strait; the minimum age is therefore greater than $3.2 \mathrm{Ma}$. The maximum age of the pre-Colvillian assemblage is based on age estimates for the Nuwok Member at Carter Creek, which range from late Oligocene (McNeil and Miller, 1990) to middle to late Neogene (Marincovich and Powell, 1991).

\section{Gubik Formation}

The upper Pliocene and Quaternary Gubik Formation consists of interfingering marine and nonmarine clastic sediments that were deposited during a series of sea-level transgressions and regressions across the broad, low-gradient arctic coastal plain of Alaska. Marine subunits of the Gubik Formation representing sea-level highstands are distinguished on the basis of stratigraphic unconformities, faunal suites, sedimentary facies, and amino acid stratigraphy (Dinter $e t$ al., 1990). At least six and possibly seven or eight late Cenozoic marine transgressions are represented by deposits of the Gubik Formation on the coastal plain. The six that are presently defined have been informally named, from oldest to youngest, the Colvillian, Bigbendian, Fishcreekian, Wainwrightian, Pelukian, and Simpsonian transgressions (Carter et al., 1986a). The Colvillian, Bigbendian, and Fishcreekian deposits are of Pliocene age (Carter and Galloway, 1985; Carter et al., 1986a; Repenning et al., 1987; Nelson and Carter, 1991; Carter and Hillhouse, 1991); the Wainwrightian, Pelukian, and Simpsonian deposits are of Pleistocene age (Carter et al., 1986a).

Colvillian Deposits: The oldest marine deposits of the Gubik Formation that have been recognized on the arctic coastal plain were deposited during the Colvillian transgression (Carter et al., 1986a), which is named for marine deposits exposed in bluffs along the lower Colville River and its tributaries. Colvillian deposits unconformably overlie Cretaceous or lower Tertiary strata throughout the extent of exposure, except in the Marsh Creek region. In the "type" area along the Colville River, where the transgression was first recognized by L.D. Carter, Colvillian deposits are overlain by $1.0-1.5 \mathrm{~m}$ of Bigbendian deposits and everywhere by 11-12 $\mathrm{m}$ of Quaternary fluvial and eolian sediments (Dinter et al., 1990).

The Colvillian transgression represents the first sea-level highstand record in northern Alaska after the opening of Bering Strait (Carter et al., 1986a), and its deposits are readily distinguished from older Pliocene deposits by the mixture of Pacific and Atlantic faunas. The presence of Pacificderived taxa thus indicates an age that post-dates the opening of Bering Strait at about 3.2 Ma (Hopkins, 1967, 1972; Gladenkov, 1981; Einarsson and Albertsson, 1988). This minimum date of $3.2 \mathrm{Ma}$ is based on a lava interbedded with sediments containing the first occurrence of Pacific mollusks in Iceland (Gladenkov, 1981); the earliest Pacific immigrants could be somewhat older than 3.2 Ma. Recent work by Gladenkov et al. (1991) suggests that the first opening of Bering Strait may have been as long ago as $4.0 \mathrm{Ma}$; the radiometric and paleomagnetic/biostratigraphic data do not agree, so the $4 \mathrm{Ma}$ age is considered to be tentative (Gladenkov and Barinov, pers. comm. 1991). A minimum age for the Colvillian is provided by the next younger sealevel event, the Bigbendian transgression, which has been dated as no older than 2.48 Ma (Carter and Hillhouse, 1991).

Strontium isotope analyses of marine mollusk shells indicate a minimum age of 1.6 Ma and a maximum age of $4.5 \mathrm{Ma}$ for Colvillian sediments (Kaufman et al., 1990). Kaufman (written comm. 1991) notes that the strontium isotope data are preliminary and that subsequent analyses suggest that 
TABLE 2. Occurrence chart of ostracode species in samples of the Gubik Formation (Colvillian sites other than the type locality and Bigbendian sites), the type Colvillian, and the pre-Colvillian at Manning Point and Barter Island (note that the letter P denotes a Pacificderived taxon)

\begin{tabular}{|c|c|c|c|c|c|c|c|}
\hline Species & $\begin{array}{c}\text { Gubik } \\
\text { (Colvillian, } \\
\text { Bigbendian) }\end{array}$ & $\begin{array}{c}\text { Type } \\
\text { Colvillian } \\
\end{array}$ & $\begin{array}{l}\text { Pre-Colvillian } \\
\text { (Barter Island } \\
\text { Manning Point) }\end{array}$ & Species & $\begin{array}{c}\text { Gubik } \\
\text { (Colvillian, } \\
\text { Bigbendian) } \\
\end{array}$ & $\begin{array}{c}\text { Type } \\
\text { Colvillian } \\
\end{array}$ & $\begin{array}{l}\text { Pre-Colvillian } \\
\text { (Barter Island } \\
\text { Manning Point) }\end{array}$ \\
\hline Acanthocythereis & & & & Elofsonella concinna & $\mathrm{X}$ & & \\
\hline dunelmensis & $X$ & & $\mathrm{X}$ & Eucythere argus & $\mathrm{X}$ & $\mathrm{X}$ & \\
\hline Argilloecia conoidea & $\mathrm{X}$ & & & Finmarchinella logani & $\mathrm{P}$ & $\mathrm{P}$ & \\
\hline Argilloecia producta & $\mathrm{X}$ & & & Hemicythere villosa & & $\mathrm{X}$ & \\
\hline Argilloecia sp. $A$ & & & $\mathrm{X}$ & Heterocyprideis fascis & $\mathrm{X}$ & & \\
\hline Bythocythere sp. $A$ & $\mathrm{X}$ & & & Heterocyprideis sorbyana & $\mathrm{X}$ & & $\mathrm{X}$ \\
\hline Cluthia cluthae & $X$ & & & Howeina colvillensis & & $\mathbf{P}$ & \\
\hline Cythere lutea & & $P$ & & Jonesia simplex & $\mathrm{X}$ & & \\
\hline $\begin{array}{l}\text { Cytheretta teshekpukensis } \\
\text { Cytheromorpha }\end{array}$ & $\mathrm{X}$ & $\mathbf{X}$ & & Krithe glacialis & $\mathrm{X}$ & & $\mathrm{X}$ \\
\hline macchesneyi & $\mathrm{X}$ & $\mathbf{X}$ & & $\begin{array}{l}\text { Loxoconcha } \\
\quad \text { venepidermoidea }\end{array}$ & $\mathrm{X}$ & $\mathrm{X}$ & \\
\hline $\begin{array}{l}\text { Cytheromorpha } \\
\text { kaliknikensis }\end{array}$ & & & & Microcytherura aff. & & & \\
\hline $\begin{array}{l}\text { Kallkpikensts } \\
\text { Cytheromorpha }\end{array}$ & $x$ & & & $\begin{array}{l}\text { M. expanda } \\
\text { Munsevella sn } A\end{array}$ & & $\mathrm{X}$ & $\mathrm{X}$ \\
\hline manningensis & $\mathrm{X}$ & & $\mathrm{X}$ & $\begin{array}{l}\text { Palmenella limicola } \\
\text { Panseye }\end{array}$ & $\begin{array}{l}\lambda \\
P\end{array}$ & & \\
\hline $\begin{array}{l}\text { Cytheropteron arcuatum } \\
\text { Cytheropteron aff. }\end{array}$ & $\mathrm{X}$ & & $\mathrm{X}$ & $\begin{array}{l}\text { Palmoconcha sp. A } \\
\text { Paracyprideis }\end{array}$ & $\mathrm{X}$ & & \\
\hline $\begin{array}{l}\text { arcuatum } \\
\text { Cytheropteron biconvexum }\end{array}$ & & & $\begin{array}{l}X \\
X \\
Y\end{array}$ & $\begin{array}{l}\text { pseudopunctillata } \\
\text { P. aff. pseudopunctillata }\end{array}$ & $\begin{array}{l}X \\
X\end{array}$ & & $\mathrm{X}$ \\
\hline $\begin{array}{l}\text { Cytheropteron carteri } \\
\text { Cytheropteron }\end{array}$ & $\mathrm{X}$ & $\mathrm{X}$ & $\mathbf{X}$ & Paradoxostoma sp. & $\mathrm{X}$ & $\mathrm{X}$ & \\
\hline $\begin{array}{l}\text { dimlingtonensis } \\
\text { Cytheropteron elaeni }\end{array}$ & $\begin{array}{l}\mathrm{X} \\
\mathrm{X}\end{array}$ & $X$ & & $\begin{array}{l}\text { Pteroloxa venepuncta } \\
\text { Pterygocythereis }\end{array}$ & $\mathrm{x}$ & & \\
\hline Cytheropteron inflatum & $\mathrm{X}$ & & & vannieuwenhuisei & $\mathrm{X}$ & & $\mathrm{X}$ \\
\hline Cytheropteron aff. & & & & Rabilimis paramirabilis & $\mathrm{X}$ & $\mathrm{X}$ & $\begin{array}{l}X \\
X\end{array}$ \\
\hline $\begin{array}{l}\text { latissimum } \\
\text { Cytheropteron montrosiense } \\
\text { Cytheropteron }\end{array}$ & $\begin{array}{l}X \\
X\end{array}$ & & & $\begin{array}{l}\text { Kabllimis afj. paramirabuls } \\
\text { Rabilimis sp. } \\
\text { Robertsonites tuberculatus }\end{array}$ & $\mathbf{P}$ & $X$ & \\
\hline paralatissimum & $\mathrm{X}$ & & $\mathrm{X}$ & Roundstonia globulifera & & & $\mathrm{X}$ \\
\hline $\begin{array}{l}\text { Cytheropteron } \\
\text { pseudomontrosiense }\end{array}$ & $\mathrm{X}$ & & $\mathbf{X}$ & $\begin{array}{l}\text { Sarsicytheridea bradii } \\
\text { Sarsicytheridea }\end{array}$ & $\mathrm{X}$ & $\mathrm{X}$ & \\
\hline Cytheropteron sedovi & $\mathrm{X}$ & & & macrolaminata & $\mathrm{X}$ & $\mathrm{X}$ & $\mathrm{X}$ \\
\hline Cytheropteron simplex & $\mathrm{X}$ & & $\mathrm{X}$ & Sarsicytheridea punctillata & $\mathrm{X}$ & & \\
\hline Cytheropteron sp. B & $\mathrm{X}$ & $\mathrm{X}$ & & Sarsicytheridea sp. $A$ & $\mathrm{X}$ & · & $\mathbf{X}$ \\
\hline Cytheropteron sp. $C$ & & & $\mathrm{X}$ & Semicytherura concentrica & $\mathrm{X}$ & & \\
\hline Cytheropteron sp. $D$ & & $\mathrm{X}$ & & Semicytherura complanata & $\mathrm{X}$ & & $\mathrm{X}$ \\
\hline Elofsonia sp. & $\mathrm{X}$ & & & Semicytherura nigrescens & & $\mathrm{X}$ & \\
\hline
\end{tabular}

the Sr composition of some shells on the arctic coastal plain have been diagenetically altered and cannot be used for chronostratigraphic purposes. Brigham-Grette and Carter (1992) estimate the age of the Colvillian transgression as between 2.48 and $2.7 \mathrm{Ma}$, based on amino acid epimerization rates and age constraints of the overlying Bigbendian transgression.

In this paper, the Colvillian transgression is considered to be younger than the opening of Bering Strait and therefore no older than 3.2 Ma, and older than the Bigbendian transgression and therefore no younger than $2.48 \mathrm{Ma}$.

Bigbendian Deposits: The Bigbendian transgression is the second oldest sea-level highstand after the opening of Bering Strait (Carter et al., 1986a,b; Carter and Hillhouse, 1991). The Bigbendian transgression is named for marine deposits exposed in bluffs along the big bend of the Colville River near Ocean Point and from the Big Bend benchmark upstream for about $10 \mathrm{~km}$ (Brigham-Grette and Carter, 1992; Fig. 2, locality 4). Bigbendian deposits unconformably overlie Cretaceous or older Tertiary strata in most places and overlie a few metres of Colvillian strata in some places (Carter and Hillhouse, 1991). Molluscan shells with amino acid racemization ratios equivalent to those from the type locality of the Bigbendian transgression are also found in the basal sediments at Fish Creek (Fig. 2, locality 2) and along the Miluveach River (Carter and Hillhouse, 1991; Fig. 2, locality 1).

Strontium isotope analyses of marine mollusks indicate a minimum age of $1.9 \mathrm{Ma}$ for Bigbendian deposits (Kaufman et al., 1990). Based on a reversed paleomagnetic polarity determination and climatic arguments, Carter and Galloway (1985) suggested that sediments of the Bigbendian transgression were deposited at $2.48 \mathrm{Ma}$. Brigham-Grette and Carter (1992) argued that a normal to reversed-polarity boundary in Bigbendian sediments on the Colville River spans the Gauss Normal-Polarity Chron and Matuyama ReversedPolarity Chron (Carter and Hillhouse, 1991), dated as 2.48 Ma (Mankinen and Dalrymple, 1979).

In this paper, the Bigbendian transgression is considered to be younger than the Colvillian transgression and older than or equal to $2.48 \mathrm{Ma}$.

Fishcreekian Deposits: The Fishcreekian transgression is the third sea-level highstand after the opening of Bering Strait (Carter et al., 1986b). The Fishcreekian transgression is 
named for fossiliferous marine beds exposed in low bluffs along Fish Creek, west of the Colville River (Fig. 2). The type section of the Fishcreekian represents tidal sediments deposited during the regressive sequence of the marine incursion. Strontium analyses of Fishcreekian mollusks indicated an age range of 0.5-1.7 Ma (Kaufman et al., 1990), but recent work suggests that diagenetic alteration of the strontium has occurred (Brigham-Grette and Carter, 1992). Based on amino acid racemization ratios, a paleomagnetic determination of reversed magnetic polarity, and the vertebrate fauna, especially the presence of the ancestral sea otter Enhydrion and the microtine Plioctomys mimomiformis, an age of about $2.40 \mathrm{Ma}$ is suggested (Carter et al., 1986b; Repenning et al., 1987; Repenning and Brouwers, 1992).

The ostracode assemblage consists of taxa essentially the same as those living today in the Beaufort Sea, suggesting subfrigid to frigid bottom water temperatures. Some of the marine mollusks and the tooth of an archaic sea otter, Enhydrion, preclude winter temperatures that would result in shoreline freezing (Repenning et al., 1987). The pollen flora shows progressive climatic severity upsection, ranging from lower shrub tundra to upper herb tundra (Repenning et al., 1987). The Fishcreekian records the end of the Bigbendian transgression and the first cooling period during the Matuyama Chron. The climate change from open forests and warm water of the Bigbendian transgression to shrub tundra and cold water of the Fishcreekian transgression occurred entirely during deposition of the lower part of the type section of the Fishcreekian (Repenning and Brouwers, 1992).

\section{OSTRACODE ASSEMBLAGES}

Qualitative observations of the ostracode assemblages from the lower part of the Gubik Formation and upper part of the Sagavanirktok Formation indicate that the samples can be sorted into two groups: one containing both Pacific- and Atlantic-derived taxa (samples from the Gubik Formation, including 81ACr6a, 83EB187, 83EB188, 85ACr120, 82ACr229, 82ACr23, 84EB51, 84EB54, 84EB60, 84EB62, $83 \mathrm{ACr} 56,80 \mathrm{AHp} 85 \mathrm{~d}, 90 \mathrm{ACr} 17 \mathrm{a} 5,90 \mathrm{ACr} 19 \mathrm{a} 1$, 90ACr19c1) and one with only Atlantic-derived taxa (samples from the Nuwok Member at Manning Point and Barter Island, including 87 ACr10, 80AHp92, 83EB68, 83EB70, 83EB71, 83EB86, 83EB87, 83EB88).

The most diverse and abundant ostracode assemblage is from the lower part of the Gubik Formation. This assemblage was originally described as constituting a distinctive warmwater fauna (Repenning et al., 1987; Marincovich et al., 1990) and was believed to represent deposition during the Colvillian transgression. Based on subsequent determinations of amino acid racemization ratios, some deposits previously ascribed to the Colvillian transgression are now thought to have been deposited during the Bigbendian transgression (L.D. Carter, written comm. 1991). Colvillian ostracode assemblages clearly cannot be differentiated from Bigbendian ostracode assemblages deposited in a similar marine environment. Localities in northeast Alaska that contain sediments and ostracode assemblages deposited during the Colvillian and Bigbendian transgressions can be viewed as two main regions: 1) the Colville River area, including exposures along the Colville and Kikiakrorak rivers, Miluveach River, Fish Creek, and the Kogru River, and 2) the north flank of the Marsh Creek anticline, including exposures along the Katakturuk River, Carter Creek, Hulahula River, Manning Point, Barter Island, and Pokok Lagoon (Figs. 2, 3).

The 23 samples analyzed in this study contain 59 ostracode species. The assemblages were analyzed using several multivariate statistical procedures to test the empirical observations and to identify additional patterns. Dissimilarity coefficients were employed to semi-quantitatively measure differences between ostracode assemblages of each sample. Three coefficients were used: the unweighted Manhattan metric, the equal weight squared standardized Euclidean distance, and the signal-to-noise squared chord distance. The Manhattan metric coefficient is most influenced by common species, the Euclidean distance coefficient up-weights less common species, and the chord distance coefficient is influenced by less common species, but to a lesser extent than equal-weight coefficients (Overpeck et al., 1985). The chord distance coefficient generated a dendrogram that best illustrates observed groupings of samples based on species associations (Fig. 4).

The technique of principal components analysis (PCA) illustrates variance between samples by means of points on axes (eigenvalues). Patterns in data are represented by clusters

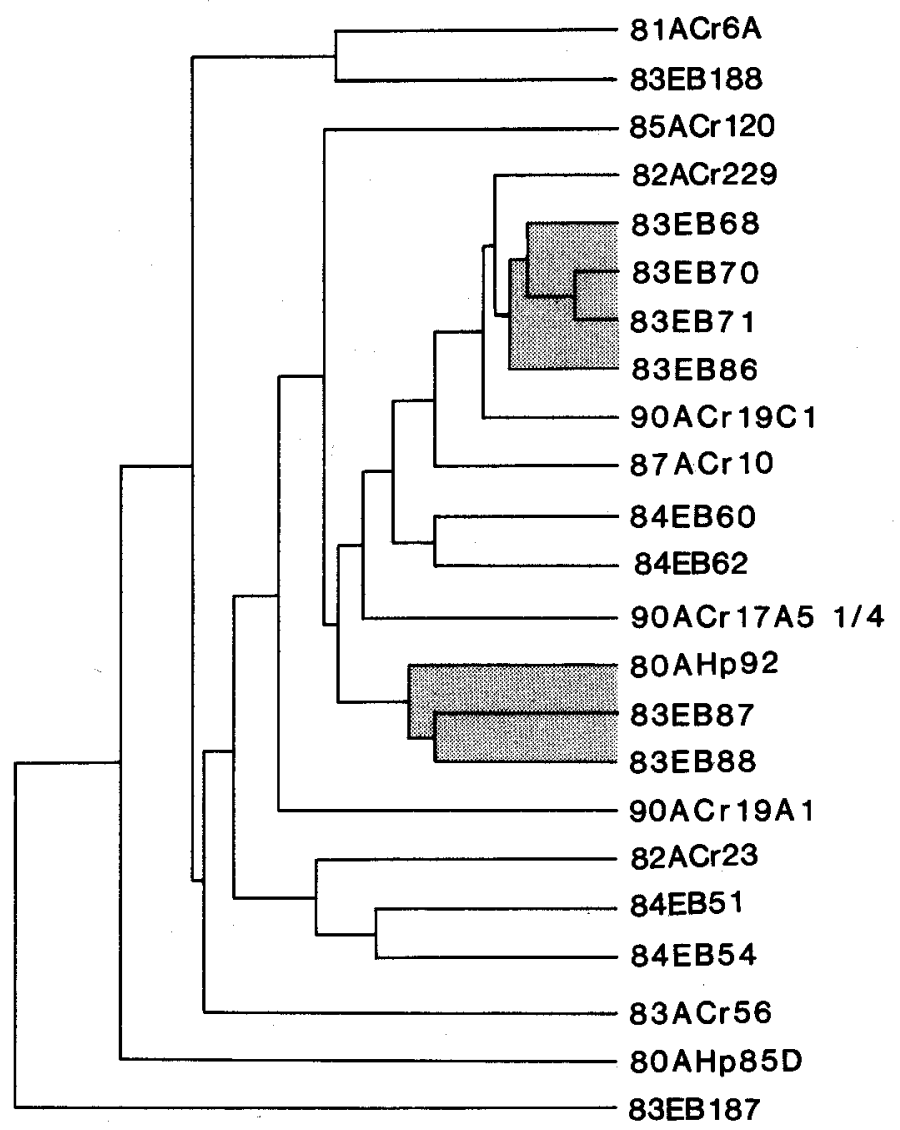

FIG. 4. Dendrogram generated by a cluster analysis using the chord distance dissimilarity coefficient. Shaded area indicates samples from Barter Island and Manning Point. 
of samples, where smaller distances between samples indicate greater commonality of species (Hazel, 1977). A principal components analysis of the 23 samples was performed. The results show that the first three principal components account for $82 \%$ of the variance in the data. Figure 5 shows PCA axes 1 and 2; Figure 6 illustrates axes 1 and 3. Pre-Colvillian, Colvillian, and Bigbendian assemblages do not group and cannot be consistently or confidently identified.

The multivariate statistical methods used do not differentiate the samples into distinct groups or clusters, highlighting the similarity of species composition. The qualitative differences noted above could not be duplicated using a variety of quantitative techniques. The dendrogram generated by the dissimilarity coefficient clustered the Manning Point and Barter Island samples into two groups (Fig. 4), but these clusters are not effectively sorted from Gubik samples. Principal components analysis grouped most of the samples into one cluster; a few samples, such as 83-EB-187, plotted far away from the main cluster, but this is probably due to the dominance of one or two species, which skews the sample from the main cluster (e.g., $47 \%$ of the valves in 83EB 187 are of Heterocyprideis fascis and Sarsicytheridea punctillata; $53 \%$ of the specimens in 80AHp85D are of Rabilimis paramirabilis and Heterocyprideis sorbyana). The similarity in species composition of pre-Colvillian, Colvillian, and Bigbendian samples is believed to reflect similar ecological conditions, especially the marine climate, during these late Pliocene high-sea-level events.

\section{Ostracode Assemblages of the Gubik Formation}

Ostracode assemblages of the lower Gubik Formation sediments can be separated into two distinct groups based on inferences about the depth of water in which the various species live and, to a lesser extent, on paleotemperature. A group of taxa characteristic of shallow-water environments occurs at the type area of the Colvillian transgression, and taxa typical of deeper water environments occur at a number of Gubik localities seaward (north) of the type area of the Colvillian transgression.

Deep-Water Fauna: The deep-water assemblage has the most diverse fauna, consisting of 50 species (Table 2). The assemblage is remarkably uniform in composition, even among localities that are widely separated geographically. Similar species associations (dominated by Acanthocythereis dunelmensis, Cytheropteron arcuatum, Elofsonella concinna, Heterocyprideis sorbyana, Krithe glacialis, Palmenella limicola, Paracyprideis pseudopunctillata, Pterygocythereis vannieuwenhuisei, Rabilimis paramirabilis, Robertsonites tuberculatus, Sarsicytheridea macrolaminata, and Sarsicytheridea punctillata) characterize the localities.

The deeper water assemblage contains a fairly high percentage of large-sized, heavy-shelled hemicytherids and trachyleberids; both adults and juveniles are present, but specimens are predominantly adults. The assemblage typically includes cytherideids such as Heterocyprideis, Paracyprideis, and Sarsicytheridea, which imply inner- to middle-shelf water depths. The presence of a diverse group of Cytheropteron species (13 species total in the Colvillian and Bigbendian deposits) is indicative of either a muddy substrate typical of offshore environments or of bottom-water temperatures warmer than arctic conditions. High species diversity of Cytheropteron can be found today in cold-temperate to subfrigid marine climates (Whatley and Masson, 1979; Brouwers, 1983).

Based on the present-day distribution of the extant species and inferences for the extinct species, the deep-water assemblage indicates a stable paleoenvironment with little fluctuation of the physical-chemical environment, conditions typical of deeper inner sublittoral to middle sublittoral water depths. Water temperatures were characteristic of the northern cold-temperate to subfrigid marine climatic zones (typified today by the Nova Scotian and Labradorian biogeographic provinces; Hazel, 1970).

Shallow-Water Fauna: The shallow-water assemblage occurs only at the type area of the Colvillian transgression

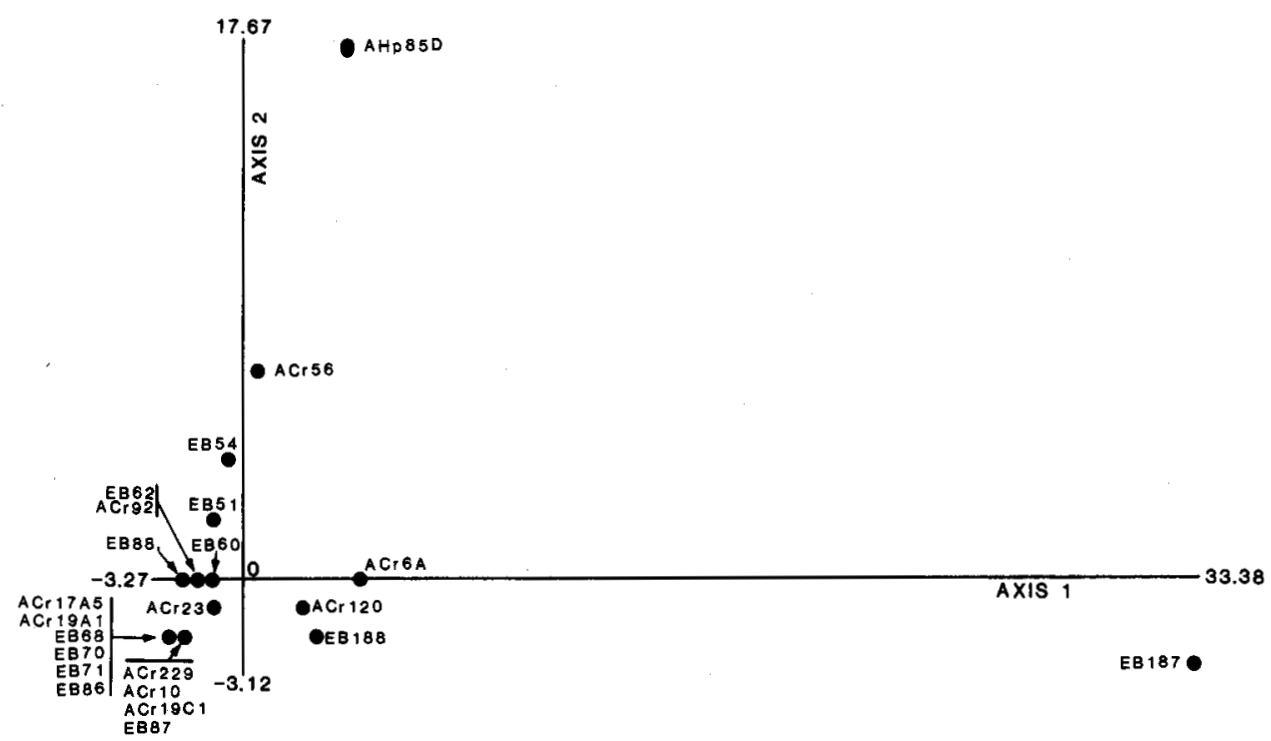

FIG. 5. Plot of the first and second principal components of ostracode assemblages from 23 samples of upper Pliocene marine deposits. 


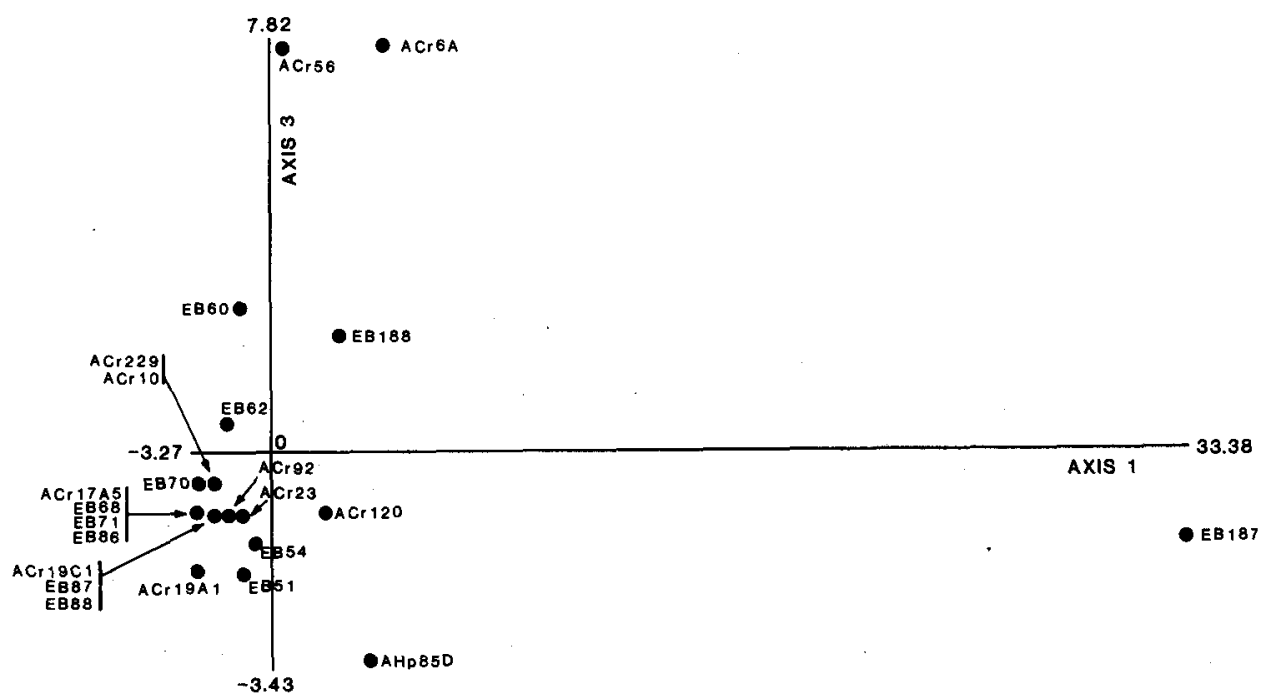

FIG. 6. Plot of the first and third principal components of the late Pliocene ostracode fauna studied.

(L.D. Carter, written comm. 1990) and is represented by three samples $(90 \mathrm{ACr} 17 \mathrm{a} 5,90 \mathrm{ACr} 19 \mathrm{a} 1,90 \mathrm{ACr} 19 \mathrm{c} 1)$ from two localities (Fig. 2, locality 4; Table 1). The assemblage shows a lower species diversity than the deep-water assemblage, consisting of 19 taxa (Table 2). The shallow-water assemblage is dominated by Hemicythere villosa, whose presence in Colvillian deposits marks the oldest known occurrence of the species in the Arctic. The other dominant species in the assemblage are Howeina colvillensis, Rabilimis paramirabilis, Sarsicytheridea bradii, and Sarsicytheridea macrolaminata.

The type area is located landward (south) of the "deeper water assemblage" localities, and the profound difference in species composition reflects differences in water depth and probably bottom water temperature. Elofson (1941) recorded Hemicythere villosa living as deep as $30 \mathrm{~m}$ but noted that it is a phytal species more common in shallow water. The other species in the assemblage are not as indicative of depth, although Semicytherura and Sarsicytheridea are more common in inner sublittoral environments in the Arctic.

The shallow-water assemblage does not contain nonmarine or low-salinity taxa, implying that the environment was probably not strongly affected by seasonal fluctuation of the physical-chemical environment. The assemblage is a mixture of taxa restricted to frigid and/or subfrigid marine climates (Cytheromorpha macchesneyi, Cytheretta teshekpukensis, Finmarchinella logani, Loxoconcha venepidermoidea, Rabilimis spp., Sarsicytheridea macrolaminata) and taxa that do not range farther north than subfrigid marine climates, such as Cythere lutea, Hemicythere villosa, Semicytherura nigrescens, Howeina spp., and Microcytherura spp.

Colvillian ostracode assemblages are dominated by Atlantic-derived genera (Sarsicytheridea, Rabilimis, Pterygocythereis, Heterocyprideis), but Pacific-derived genera have their first appearance in the Arctic in Colvillian sediments (e.g., Finmarchinella, Hemicythere, Howeina, Palmenella, Pectocythere, Robertsonites). The presence of Howeina is particularly noteworthy because this genus has never been reported from the Atlantic or Arctic, and it is an outstanding example of a temperate climate Pacific immigrant that has migrated from shallow marine environments around Japan. The Colvillian deposits mark the onset of a tremendous faunal exchange from the Pacific Ocean to the Atlantic Ocean. Water temperatures were warm enough to allow many genera originally temperate in nature to move northward - some of these genera evolved species that now make up the distinct arctic fauna. After the Colvillian and Bigbendian transgressions, sea temperatures began to significantly cool (Carter et al., 1986b; Repenning et al., 1987), causing the temperate species to migrate to lower latitudes and warmer waters or to go extinct.

\section{PALEOTEMPERATURE ANALYSIS}

Figure 7 illustrates the temperature range of 33 extant species that occur in the assemblages from the Gubik and Sagavanirktok formations. These data are taken from a modern data set of 329 high-latitude shallow-marine samples (Cronin et al., 1991) that examined the distribution of 97 ostracode species from the Arctic. The average summer bottom-water temperature of the extant species ranges from a low of about $-0.8^{\circ} \mathrm{C}$ to a high of about $9^{\circ} \mathrm{C}$, with most species showing average summer bottom temperatures of $0-4^{\circ} \mathrm{C}$, or as much as $5^{\circ} \mathrm{C}$ warmer than summer bottom-water temperatures of the present-day Beaufort Sea continental shelf.

Figure 8 shows the bottom temperature of 15 extant ostracode genera that occur both in the Gubik and Sagavanirktok assemblages and in a data set compiled by Cronin and Dowsett (1990). The data are taken from a modern suite of 100 shallow-marine samples from the North Atlantic (Cronin and Dowsett, 1990). The mean February (winter) bottom temperature of the 15 genera ranges from a minimum of $-1^{\circ} \mathrm{C}$ to a maximum of about $15^{\circ} \mathrm{C}$, with most showing winter bottom temperatures of $0-5^{\circ} \mathrm{C}$, or about $2-7^{\circ} \mathrm{C}$ warmer than winter bottom-water temperatures in the Beaufort Sea today. The mean August (summer) bottom temperature of the genera ranges from $0^{\circ} \mathrm{C}$ to $20^{\circ} \mathrm{C}$, with most showing 


\section{Summer bottom temperature in degrees celsius}

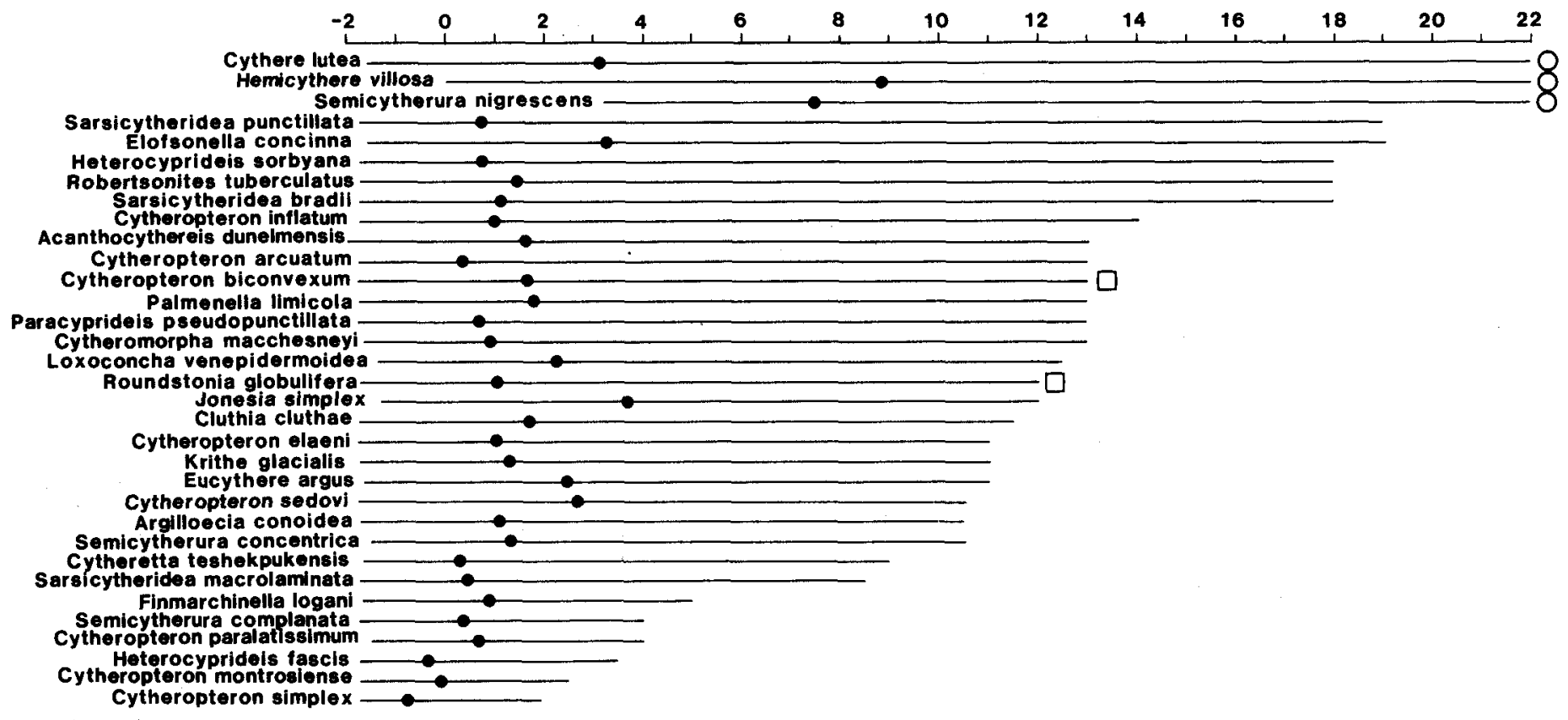

Modern August bottom temperature, Alaskan Beaufort Sea

FIG. 7. Average summer (solid circle) and survival temperature range (horizontal line) of 33 extant ostracode species occurring in samples from the Gubik Formation and Nuwok Member of the Sagavanirktok Formation and in the data set compiled by Cronin et al. (1991; unpubl. data). The data set consists of 97 ostracode species occurring in 329 modern samples from shallow water arctic sites. The three open circles denote species restricted to the type Colvillian; the two open squares denote species restricted to the pre-Colvillian; the remaining 28 species occur in Colvillian and Bigbendian deposits.

summer bottom temperatures of $2-5^{\circ} \mathrm{C}$, or about $2-5^{\circ} \mathrm{C}$ warmer than temperatures today.

The presence of endemic species that probably originated in the arctic regions, such as Cytheretta teshekpukensis, Heterocyprideis sorbyana, Paracyprideis pseudopunctillata, Sarsicytheridea bradii, Semicytherura complanata, Rabilimis spp., Loxoconcha venepidermoidea, and Pteroloxa venepuncta, indicate that the bottom water of the Arctic Ocean had undergone some cooling by Colvillian time. However, the presence of several extralimital taxa such as Semicytherura nigrescens, Pterygocythereis, Microcytherura, and Munseyella, which live today in marine climates no colder than subfrigid, indicates that water temperatures were not frigid.

Colvillian and Bigbendian Ostracodes: Twenty-eight of the 33 extant ostracode species illustrated in Figure 7 occur in Colvillian and Bigbendian sediments; the remaining 5 species are restricted to the pre-Colvillian or to the type Colvillian. The temperature ranges of these 28 species are shown in Figure 7, with temperature data derived from the modern data set of Cronin et al. (1991). The average summer bottom temperatures of these species range from $-1^{\circ} \mathrm{C}$ to $4^{\circ} \mathrm{C}$, with most species indicating $0-3^{\circ} \mathrm{C}$, or about $1-4^{\circ} \mathrm{C}$ warmer than today.

A plot showing the temperature ranges of 8 extant genera that occur in the type Colvillian samples (Cythere, Eucythere, Finmarchinella, Hemicythere, Loxoconcha, Paradoxostoma, Sarsicytheridea, Semicytherura; Fig. 8) indicates mean winter (February) sea bottom temperatures of $-1^{\circ} \mathrm{C}$ to $13^{\circ} \mathrm{C}$, with most genera indicating $0-2^{\circ} \mathrm{C}$, or about $2-4^{\circ} \mathrm{C}$ warmer than today. The mean summer (August) sea-bottom temperature ranges of these genera is between $1^{\circ} \mathrm{C}$ to $20^{\circ} \mathrm{C}$, with an average of $9^{\circ} \mathrm{C}$, or about $9^{\circ} \mathrm{C}$ warmer than today. This high average summer temperature is probably biased because a North Atlantic sample set was used for comparison. The species-level estimate is probably more relevant for Alaska, because it uses a higher order taxonomic level and is based on a high-latitude (arctic) sample set.
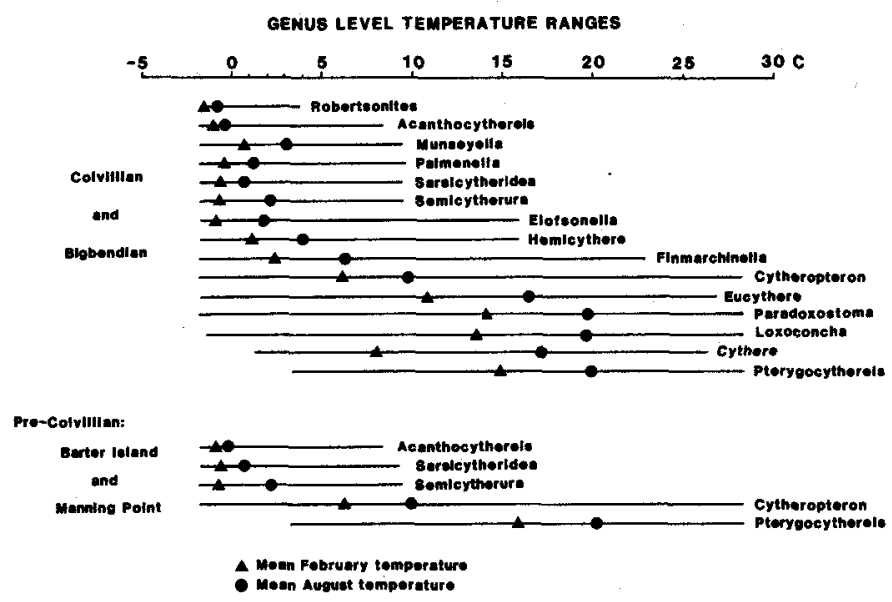

FIG. 8. Mean- and survival-temperature range, based on latitudinal distribution, for 15 extant ostracode genera occurring both in the Gubik Formation and Nuwok Member of the Sagavanirktok Formation and from data of Cronin and Dowsett (1990). Filled circle represents mean February bottom temperature; filled triangle represents mean August bottom temperature. 
Pre-Colvillian Ostracodes from Manning Point and Barter Island: The pre-Colvillian assemblage contains many of the same species as the Gubik assemblages (Table 2), with the notable absence of Pacific-derived taxa. The extant species that occur in the Nuwok samples from Manning Point and Barter Island (e.g., Acanthocythereis dunelmensis, Cytheropteron arcuatum, $C$. biconvexum, C. pseudomontrosiense, C. simplex, Heterocyprideis sorbyana, Krithe glacialis, Paracyprideis pseudopunctillata, Roundstonia globulifera, Sarsicytheridea macrolaminata, Semicytherura complanata) are indicative of subfrigid to frigid marine climates (Hazel, 1970; Cronin et al., 1991). The pre-Colvillian ostracode fauna indicates colder water conditions than are inferred for the ostracode assemblages from the type Nuwok Member (Fouch et al., 1990) and comparable water temperatures to those inferred for the younger Colvillian and Bigbendian assemblages of the Gubik Formation.

At the genus level, the pre-Colvillian assemblage (Fig. 8) indicates mean February (winter) bottom temperatures of $-1^{\circ} \mathrm{C}$ to $16^{\circ} \mathrm{C}$, with an average of about $5^{\circ} \mathrm{C}$, and mean August (summer) bottom temperatures of $0^{\circ} \mathrm{C}$ to $20^{\circ} \mathrm{C}$, with an average of $9^{\circ} \mathrm{C}$. Eleven extant species occur in the preColvillian samples, and their modern temperature range is shown in Figure 7. The average summer bottom water temperature of the extant species ranges from $-1^{\circ} \mathrm{C}$ to $2^{\circ} \mathrm{C}$, with most species falling between $0-2^{\circ} \mathrm{C}$, or $1-3^{\circ} \mathrm{C}$ warmer than today. The species-level data set is considered to be more representative of bottom temperatures than the genus-level data set.

\section{PALEOGEOGRAPHIC RECONSTRUCTIONS}

Paleogeographic reconstructions of the Northern Hemisphere indicate that, during the time period after the Cretaceous and up to the late Pliocene, the Arctic Ocean was connected to the world oceans only through the North Atlantic and Turgai Strait; the Pacific connection through the Bering Strait was closed until about $3 \mathrm{Ma}$ (Marincovich et al., 1990). During most of the Tertiary, therefore, no marine exchange was possible between the Pacific and the Arctic/North Atlantic oceans. The ostracode assemblage from Manning Point and Barter Island is exclusively Atlantic in character, suggesting that a connection to the Pacific Ocean by way of the Bering Strait had not yet come into existence.

The modern geographic position of the Northern Hemisphere land masses consists of a closed Isthmus of Panama and an open Bering Strait. The closing of the Central American Seaway in the late Pliocene (about 3-4 Ma; Keigwin, 1982; Jones and Hasson, 1985) has been linked to the formation of Northern Hemisphere ice sheets (Kennett, 1982). The northward deflection of the westward-flowing North Equatorial Current resulted in a more vigorous Gulf Stream, which was one of the final stages in the development of modern North Atlantic circulation (Berggren and Hollister, 1977; Kennett, 1982). Increased northward transport of warm water by the Gulf Stream would have significantly increased precipitation in high latitudes, resulting in greater cloud and snow cover, a positive feedback to high latitude cooling and ice formation (Arthur, 1979; Kennett, 1982).
Raymo et al. (1990) presented an atmospheric general circulation model in which arctic sea ice limits were substantially reduced all months; this model predicted only minor summer temperature changes and $15-20^{\circ} \mathrm{C}$ winter temperature changes, all occurring in areas immediately adjacent to areas that lost sea ice. Raymo et al. (1990) suggested that global cooling associated with North American and Eurasian glaciation, tectonic movements (e.g., Late Cenozoic uplift of the Tibetan and Colorado plateaus; Ruddiman and Kutzbach, 1989), and/or long-term atmospheric $\mathrm{CO}_{2}$ changes driven by uplift (Raymo et al., 1988) could have initiated both winter and summer cooling of the arctic region. The late Pliocene ostracode faunas analyzed here indicate that summer and winter cooling between $3 \mathrm{Ma}$ and $2.4 \mathrm{Ma}$ was not significantly different and was not on the order of $15-20^{\circ} \mathrm{C}$, as speculated by Raymo et al. (1990), but rather was $1-5^{\circ} \mathrm{C}$, with a maximum predicted of $9^{\circ} \mathrm{C}$. Maximum contrast between ocean and land was during the Fishcreekian transgression, when shrub tundra occurred onshore and a subfrigid marine climate with no winter freezing occurred along the coast (Repenning and Brouwers, 1992).

The pre-Colvillian assemblage is believed to represent conditions of the Arctic Ocean just prior to the opening of Bering Strait. Water temperatures were cold-temperate to subfrigid, and the ostracode fauna consisted of endemic arctic and Atlantic-derived taxa. The Colvillian assemblage represents conditions just after the opening of Bering Strait. Water temperatures were cold-temperate to subfrigid, and the ostracode fauna consisted of a mixture of endemic arctic, Atlantic-derived, and newly introduced Pacific-derived taxa. Deposits of the next sea-level highstand, the Bigbendian transgression, contain an ostracode assemblage essentially identical to the deep-water assemblage of the Colvillian transgression. Cythere and Hemicythere do not occur in Bigbendian deposits, having presumably migrated to warmer, lower latitude environments in the Pacific and North Atlantic, where they are reported in the Quaternary record. These two genera do not reappear in Alaskan waters until the warm Pelukian transgression at $125 \mathrm{ka}$. Colder water genera such as Rabilimis, Sarsicytheridea, Paracyprideis, and Heterocyprideis replace the warm-water taxa in the post-Bigbendian sediments of the Fishcreekian transgression (Repenning et al., 1987). The younger Fishcreekian transgression represents conditions during or just prior to the development of perennial arctic sea ice. Marine mollusks and a sea otter indicate that sea ice did not develop nearshore; the ostracode assemblage is composed of cold-water species nearly indistinguishable from a modern assemblage (Repenning et al., 1987; Repenning and Brouwers, 1992).

\section{SUMMARY}

Ostracode assemblages were examined from the Nuwok Member of the Sagavanirktok Formation at Manning Point and Barter Island and from the lower part of the Gubik Formation. The 23 samples analyzed were collected from outcrops of the eastern coastal plain of the Alaskan North Slope. Fifty-nine species were identified, of which 39 were 


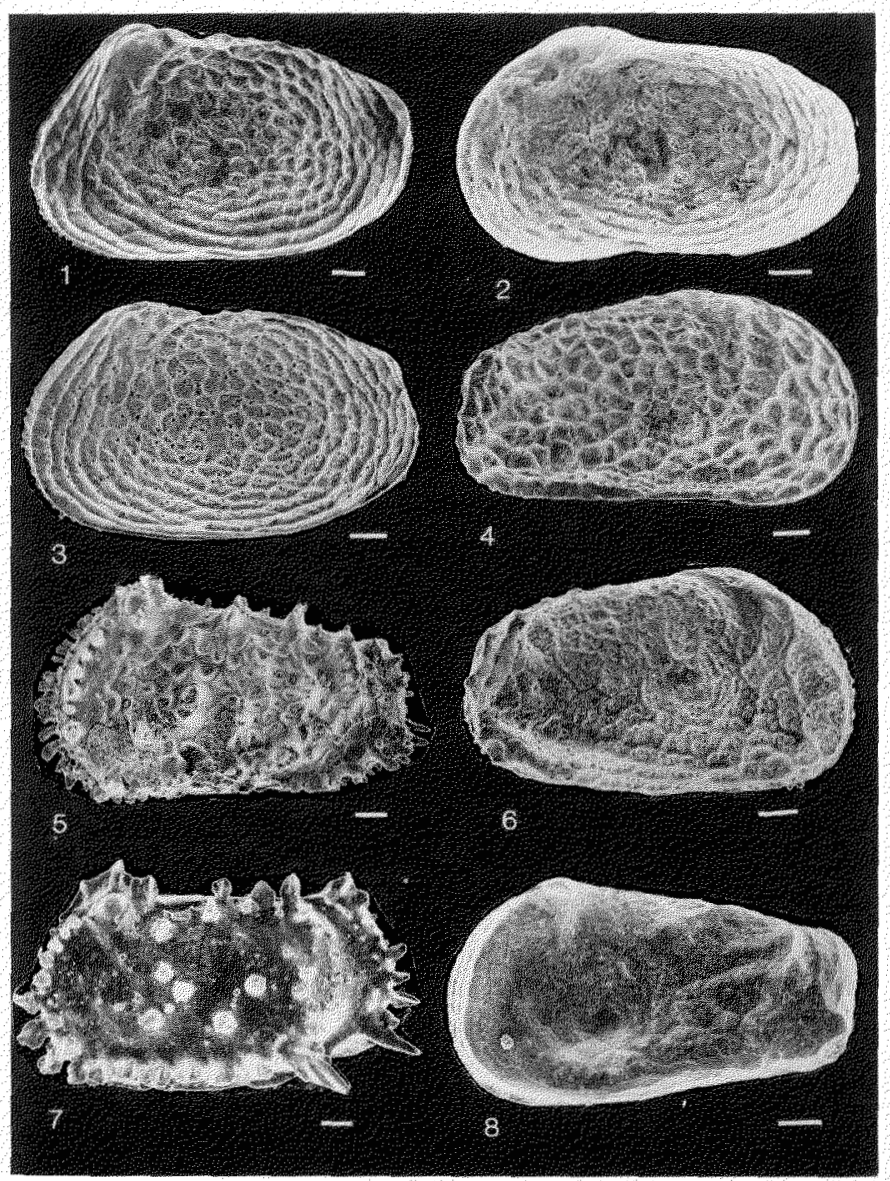

FIG. 9. All figures are scanning electron photomicrographs. White bar equals $100 \mu \mathrm{m}$. 1) Rabilimis paramirabilis (Swain, 1963), sample 83EB187, female left valve. 2) Rabilimis sp., sample 90ACr17A5, male right valve. 3) Rabilimis aff. $R$. paramirabilis (Swain, 1963), sample 83EB186, female left valve. 4) Robertsanites tuberculatus (Sars, 1866), sample 83EB187, male right valve. 5) Acanthocythereis dunelmensis (Norman, 1865), sample $85 \mathrm{ACr} 120$, fermale left valve. 6) Robertsonites tuberculatus (Sars, 1866), sample 80AHp85d, female right valve. 7) Pterygocythereis vannieuwenhuisei Brouwers, 1987, sample 83EB187, female left valve. 8) Elofsonella concinna (Jones, 1857), sample 81ACr6a, male left valve.

previously described, 4 represent new species, and 16 are retained in open nomenclature. Of the $\mathbf{4 3}$ formally named taxa, 36 are extant and 7 are extinct (most of the species are illustrated in Figs. 9-16). Six species are Pacific-derived, 12 are arctic endemics, and 25 are Atlantic-derived.

The ostracode faunas represent a time frame in the late Pliocene between about 4 and $2.48 \mathrm{Ma}$, during which the marine climate of the shallow Arctic Ocean shifted from a warm period to the onset of significant cooling and the beginning of Northern Hemisphere continental glaciation. The samples represent two transgressive events. The older fauna is probably between 4 and $3 \mathrm{Ma}$ and occurs in the Nuwok Member of the Sagavanirktok Formation at Manning Point and Barter Island. Ostracode taxa are Atlantic- and arctic-derived and indicate a cold-temperate to subfrigid marine climate, based on extant species in the assemblage. Summer bottom temperatures are inferred to be $1-3^{\circ} \mathrm{C}$ warmer than today. The younger fauna is probably between 3 and $2.48 \mathrm{Ma}$ and occurs in Colvillian and Bigbendian sediments of the lower part of the Gubik Formation. Ostracode taxa are a mixture of Atlantic, arctic, and Pacific elements and indicate a cold-temperate to subfrigid marine climate. Summer bottom temperatures are inferred to be $1-4^{\circ} \mathrm{C}$ warmer than today. The younger assemblage can be further subdivided into a deep-water fauna, represented by most of the Colvillian and Bigbendian samples, and a shallow-water fauna, represented by three samples from the type Colvillian. The shallow water assemblage contains two species that have never been reported from the Arctic, Hemicythere villosa and Howeina colvillensis. $H$. villosa is extant and has an annual temperature range of $0-22^{\circ} \mathrm{C}$, with average August temperatures of $9^{\circ} \mathrm{C}$, which is $9^{\circ} \mathrm{C}$ warmer than temperatures today.

\section{SYSTEMATIC PALEONTOLOGY}

Class OSTRACODA Latreille, 1806

Order PODOCOPIDA G.W. Mueller, 1894

Suborder PODOCOPA Sars, 1866

Superfamily CYTHERACEA Baird, 1850

Family CYTHERIDAE Baird, 1850

Subfamily CYTHERINAE Baird, 1850

Tribe CYTHERINI Baird, 1850

Genus CYTHEROMORPHA Hirschmann, 1909

Type species: Cythere fuscata Brady, 1869.

Cytheromorpha kalikpikensis new species

Figure 13-5

Diagnosis: A species of Cytheromorpha characterized by a short, squared valve shape, subparallel dorsal and ventral margins, concentrically arranged pits, and marginal reticulation.

Description: In lateral view, left valve is quadrate in shape. Dorsal margin is straight; anterior margin is evenly curved; ventral margin is relatively straight, with a shallow, broad concavity; posterior margin is truncated. Greatest length through valve midline; greatest height through anterior hinge element. Oblique anterodorsal cardinal angle; rounded posterodorsal cardinal angle.

Ornament consists of pitting and reticulation. The pits are ovoid in shape and shallow and are largest in the median valve area, becoming smaller toward the margins. The pits are arranged roughly in a concentric pattern, especially developed at the margins. Superimposed reticulation is expressed along the margins, seen as a series of fine ridges parallel to the valve outline.

Material: 26 valves.

Etymology: After the Kalikpik River, North Slope, Alaska. Occurrence: Samples 81ACr6a, 84EB51, 84EB54, 84EB60; Bigbendian.

Comparisons: Cytheromorpha kalikpikensis differs from C. manningensis by its straight dorsal margin, greater lateral compression, different size and arrangement of medial ornament pits, weak anterior reticulation, and fine punctae along the anterior margin.

\section{Cytheromorpha manningensis new species}

Figure 13-7

Cytheromorpha sp. 1 (Brouwers et al., 1991:264-265, Pl. 3, Fig. 6).

Diagnosis: A species of Cytheromorpha characterized by a short quadrate valve shape, laterally compressed carapace, and large, shallow ornament pits. 
Description: In lateral view, right valve is quadrate in shape. Dorsal margin is straight, angling down toward the posterior; anterior margin is smoothly rounded, with the greatest width slightly ventral of mid-margin; ventral margin with a broad, shallow concavity; posterior margin truncated, nearly straight. Dorsal and ventral margins converge toward the posterior.

Valve surface covered with pits and reticulation. Primary ornament consists of large, shallow pits, ovoid to elongate in shape, covering the valve. The pitting becomes smaller marginally. Pits are arranged concentrically along the margins and in vertical rows in the median valve area. Superimposed reticulation, expressed more strongly as concentric ridges, occurs along the margins.

Material: 16 valves.

Etymology: After Manning Point, North Slope, Alaska.

Occurrence: Samples 82ACr23, 83EB87, 83EB88; pre-Colvillian, Bigbendian. Kap Kobenhavn Formation, Member B, unit B2, north Greenland.

Tribe PECTOCYTHERINI Hanai, 1957

Genus MUNSEYELLA van den Bold, 1957

Type species: Toulminia hyalokystis Munsey, 1953. Munseyella sp. A

Figure 10-8

Comments: The species illustrated by Figure $10-8$ is probably conspecific with Paijenborchella sp. $B$ of Ishizaki and Matoba (1985), described from the Sasaoka Formation, Gojonome, Hokkaido, Japan, of early Pleistocene age. The associated ostracodes in the Japanese assemblage indicate mild- to cold-temperate water temperatures. This taxon is probably not a Paijenborchella, being better placed, based on valve characters, into Munseyella (see Brouwers, 1990). Munseyella occurs in middle to outer sublittoral water depths in the Gulf of Alaska and shows poleward emergence. Its occurrence in sample $85 \mathrm{ACr} 120$, which has been identified as Fishcreekian in age based on amino acid racemization ratios (L.D. Carter, written comm. 1991) is unusual and represents a significant extension of known temperature tolerance for this extinct taxon. The mollusk and vertebrate fauna from Fishcreekian deposits indicate a cold-temperate to subfrigid marine climate; the ostracode fauna implies a subfrigid to frigid marine climate (Repenning et al., 1987; Repenning and Brouwers, 1992).

Family CYTHERIDEIDAE Baird, 1850

Subfamily CYTHERIDEINAE Sars, 1925

Genus PARACYPRIDEIS Klie, 1929

Type species: Paracyprideis fennica (Hirschmann, 1909). Paracyprideis aff. P. pseudopunctillata Swain, 1963

\section{Figure 11-5}

Comments: The specimen illustrated by Figure 11-5 is identified as a separate entity distinguished from Paracyprideis pseudopunctillata by the presence of a spine at the posteroventral corner. In Alaska, this form has been found in Bigbendian, Colvillian, and pre-Colvillian deposits. I originally believed the taxon to represent a new species that went extinct when marine climates cooled at about $2.4 \mathrm{Ma}$. However, Penney (1990) illustrates the spinose form from lower Pleistocene sediments of the central North Sea.

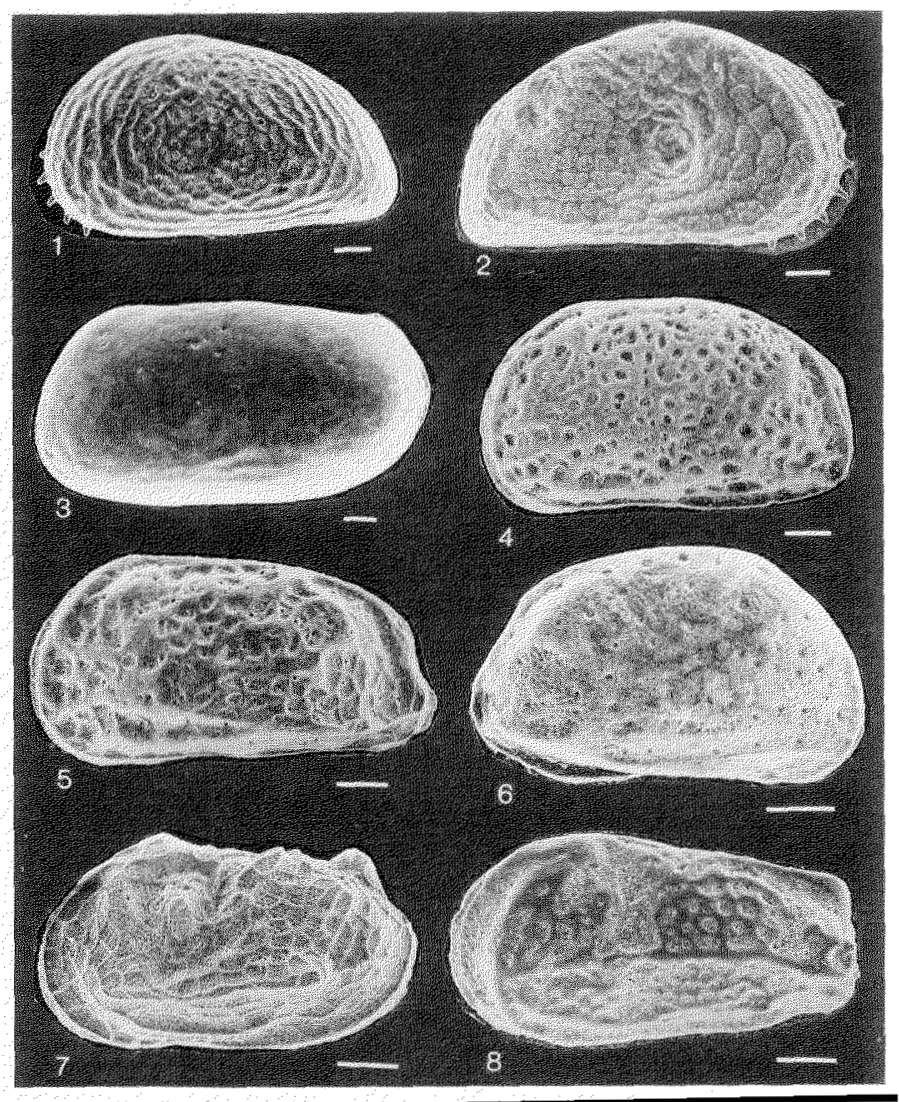

FIG. 10. All figures are scanning electron photomicrographs. White bar equals $100 \mu \mathrm{m}$. 1) Heterocyprideis sorbyana (Jones, 1857), sample 81ACr6a, male left valve. 2) Heterocyprideis fascis (Brady and Norman, 1889), sample 83EB187, female right valve. 3) Cytheretta teshekpukensis Swain, 1963, sample 83ACr56, female left valve. 4) Hemicythere villosa (Sars, 1866), sample 90ACr17A5 1/4, female left valve. 5) Finmarchinella logani (Brady and Crosskey, 1871), sample 90ACr17A5 1/4, female left valve. 6) Cythere lutea Mueller, 1785, sample 90ACr17A5 1/4, right valve. 7) Palmenella limicola (Norman, 1865), sample $82 \mathrm{ACr} 23$, female left valve. 8) Munseyella sp. $A$, sample 85 ACr120, left valve.

Therefore, I am differentiating the spinose form, but will not describe it until the stratigraphic and geographic distribution is better understood.

Genus SARSICYTHERIDEA Athersuch, 1982

Type species: Cythere bradii Norman, 1865.

\section{Sarsicytheridea sp. A}

Figure 11-4

Comments: This species probably represents a new species, differing from Sarsicytheridea punctillata, S. bradii, and $S$. macrolaminata in shape and ornament. Ornament in Sarsicytheridea sp. A consists of a predominantly smooth valve surface with fine pitting and fine-scale superimposed reticulation, both present along the anterior and posterior marginal areas. The finely pitted ornament of this taxon is very similar to an undescribed Sarsicytheridea species from the Nuwok Member of the Sagavanirktok Formation (Brouwers, unpubl.). Of interest is that Sarsicytheridea sp. $A$ occurs in the upper part of the Nuwok Member at Manning Point.

Family TRACHYLEBERIDIDAE Sylvester-Bradley, 1948 Subfamily TRACHYLEBERIDINAE Sylvester-Bradley, 1948 


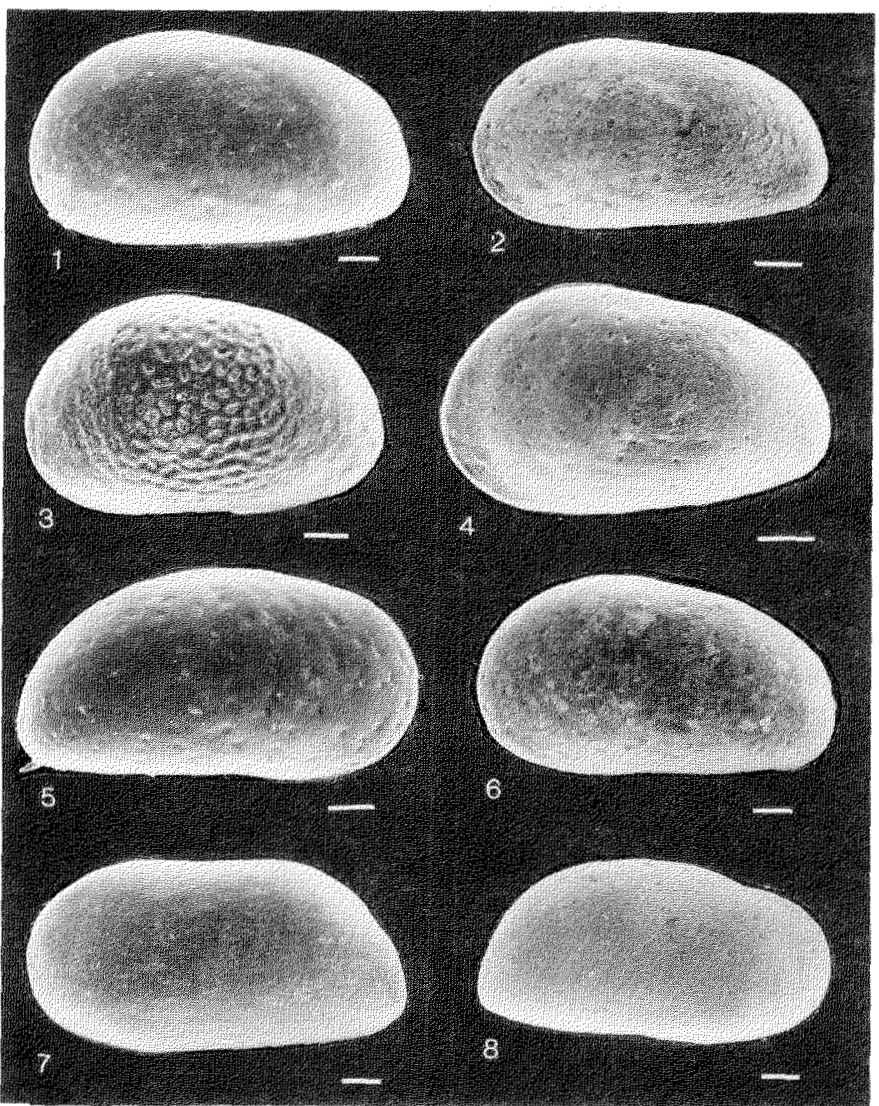

FIG. 11. All figures are scanning electron photomicrographs. White bar equals $100 \mu \mathrm{m}$. 1) Paracyprideis pseudopunctillata Swain, 1963, sample 81 ACr6a, left valve, 2) Sarsicytheridea macrolaminata (Elofson, 1939), sample 81ACr6a, left valve. 3) Sarsicytheridea punctillata (Brady, 1865), sample 81ACr6a, female left valve. 4) Sarsicytheridea sp. $A$, sample 83EB88, female left valve. 5) Paracyprideis aff. $P$. pseudopunctillata Swain, 1963, sample 84EB54, right valve. 6) Paracyprideis pseudopunctillata Swain, 1963, sample 81 ACr6a, left valve. 7) Krithe glacialis Brady, Crosskey and Robertson, 1874, sample 81ACr6a, left valve. 8) Krithe glacialis. Brady, Crosskey and Robertson, 1874, sample 82ACr23, right valve.

Tribe TRACHYLEBERIDINI Sylvester-Bradley, 1948 Genus ACANTHOCYTHEREIS Howe, 1963

Type species: Acanthocythereis araneosa Howe, 1963. Acanthocythereis dunelmensis (Norman, 1865)

Figure 9-5

Comments: The specimen illustrated by Figure 9-5 represents the larger form of Acanthocythereis dunelmensis as described by Athersuch et al. (1989) and illustrated by Elofson (1941) and Neale and Howe (1975). Athersuch et al. (1989) noted that females of the larger form of Acanthocythereis dunelmensis lack posteroventral clavate spines. Elofson identified the larger form as occurring in water temperatures ranging from a minimum of $-1.71^{\circ} \mathrm{C}$ to a maximum of $11^{\circ} \mathrm{C}$, with seasonal variance no greater than $4-11^{\circ} \mathrm{C}$. The larger form is less eurythermic, although present in subzero temperatures, but is more stenohaline than the smaller form, being found only in salinities greater than or equal to $32 \%$. The larger form has been recovered from 50-400 $\mathrm{m}$ water depth (Elofson, 1941).

Tribe PTERYGOCYTHEREIDINI Puri, 1957 Genus PTERYGOCYTHEREIS Blake, 1933
Type species: Cythereis jonesii Baird, 1850.

Pterygocythereis vannieuwenhuisei Brouwers, 1987 Figure 9-7

Comments: The specimen illustrated in Figure 9-7 is from the Kalikpik River, which has been "dated," based on the amino acid D/L ratio of Hiatella arctica, as Bigbendian (L.D. Carter, written comm. 1991). In the original paper describing this species, I noted that the taxon apparently became extinct after the Colvillian transgression. Additional data since that paper have identified that 1) some of the sites thought to be Colvillian on the basis of ostracode assemblages are Bigbendian and 2) Pterygocythereis vannieuwenhuisei has been identified from the Bridlington Crag (J. Whittington, pers. comm. 1988), of late Pliocene to early Pleistocene age. These data imply that in Alaska the so-called "Colvillian ostracode assemblage" ranges through the Bigbendian and the warm water taxa of that assemblage became locally extinct by the late Fishcreekian transgression, by which time a cold, shallow water ostracode fauna had replaced the "Colvillian assemblage" (Repenning et al., 1987; Repenning and

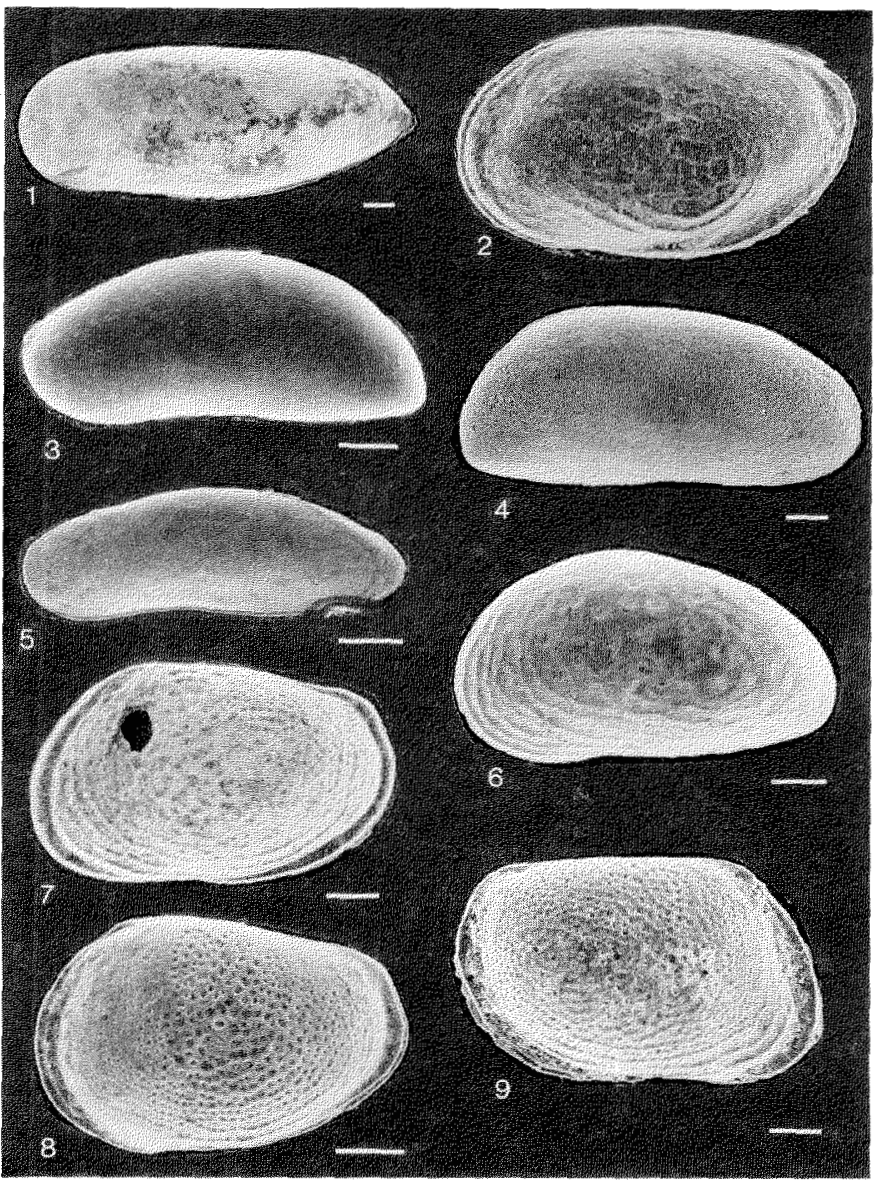

FIG. 12. All figures are scanning electron photomicrographs. White bar equals $100 \mu \mathrm{m}$. 1) Jonesia simplex (Norman, 1865), sample 84EB51, left valve. 2) Bythocythere sp. $A$, sample $82 \mathrm{ACr} 23$, left valve. 3) Argilloecia conoidea Sars, 1923, sample 84EB54, left valve. 4) Argilloecia sp. A, sample 83EB86, right valve. 5) Argilloecia producta (Brady), sample 84EB54, left valve. 6) Eucythere argus (Sars, 1866), sample 90ACr17A5 1/4, female left valve. 7) Loxoconcha venepidermoidea Swain, 1963, sample 90ACr19A1, left valve. 8) Palmoconcha sp., sample 81ACr6a, left valve. 9) Loxoconcha venepidermoidea Swain, 1963 , sample $87 \mathrm{ACr} 10$, right valve. 


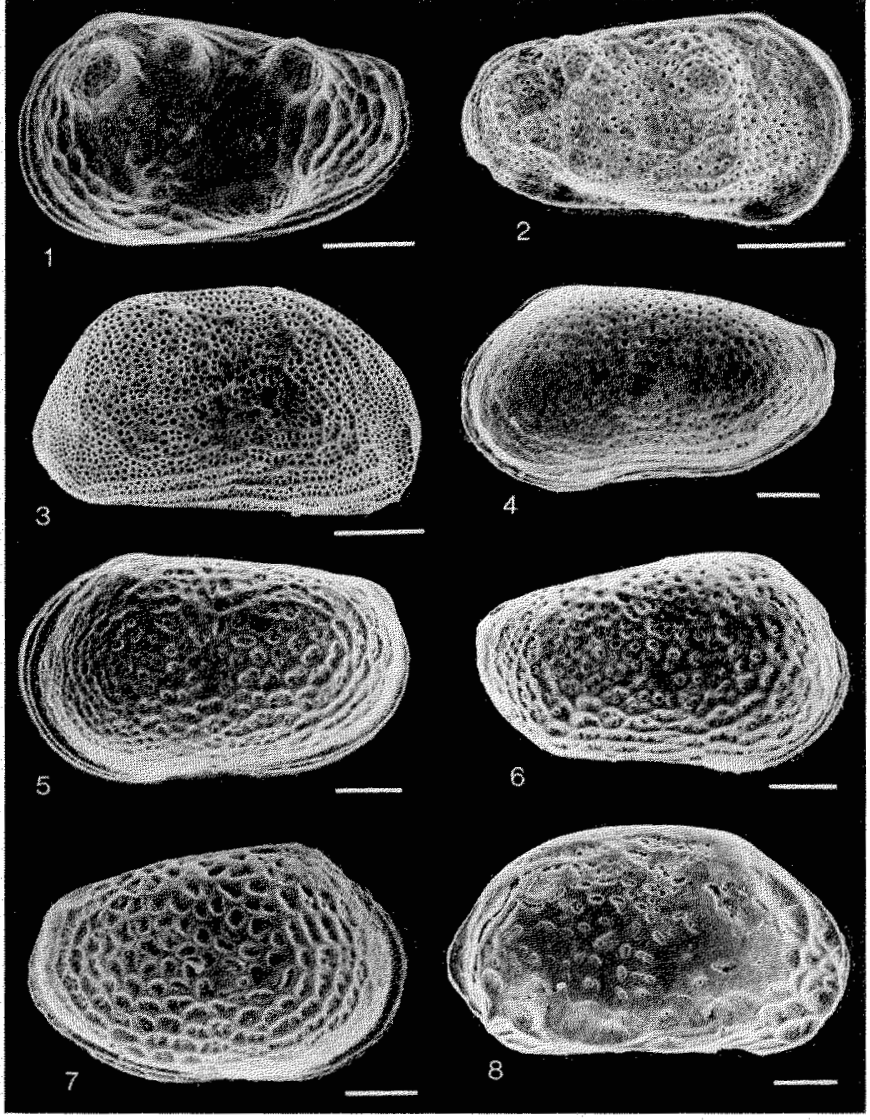

FIG. 13. All figures are scanning electron photomicrographs. White bar equals $\mu \mathrm{m}$. 1) Roundstonia globulifera (Brady, 1868), sample 83EB88, left valve. 2) Cluthia cluthae (Brady, Crosskey and Robertson, 1874), sample 84EB54, right valve. 3) Microcytherura aff. $M$. expanda Hazel, 1977, sample 90ACr17A5 1/4, right valve. 4) Cytheromorpha macchesneyi (Brady and Crosskey, 1871), sample 90ACr17A5 1/4, male left valve. 5) Cytheromorpha kalikpikensis n. sp., sample 81ACr6a, holotype, USNM 408617, female left valve. 6) Pteroloxa venepuncta Swain, 1963, sample 81 ACr6a, right valve. 7) Cytheromorpha manningensis $\mathrm{n}$. sp., sample 83EB87, holotype, USNM 408618, right valve. 8) Howeina colvillensis n. sp., sample 90ACr17A5 1/4, holotype, USNM 408619, right valve.

Brouwers, 1992). Some Colvillian-Bigbendian species, such as Pterygocythereis vannieuwenhuisei, apparently migrated into the North Atlantic during the late Pliocene, where they are believed to have occupied a refugium characterized by cold-temperate to subfrigid water temperatures.

Tribe COSTAINI Hartmann and Puri, 1974

Genus ROBERTSONITES Swain, 1963

Type species: Robertsonites gubikensis Swain, 1963.

Robertsonites tuberculatus (Sars, 1866)

Figures 9-4, 9-6

Cythereis tuberculata Sars, 1866:37.

Robertsonites gubikensis Swain, 1963:821, Pl. 98, Figs. 8a,b; Pl. 99, Fig. 12; text-Fig. 9b.

Robertsonites tuberculatina Swain, 1963:822, P1. 98, Fig. 10; Pl. 99, Fig. 1; text-Fig. 9c.

Robertsonites tuberculatus (Sars) Horne, 1983:39-52.

Comments: The two specimens illustrated by Figures $9-4$ and 9-6 show significant differences in ornament and were initially identified as separate species. Horne (1983) illustrated Robertsonites tuberculatus from many modern and fossil

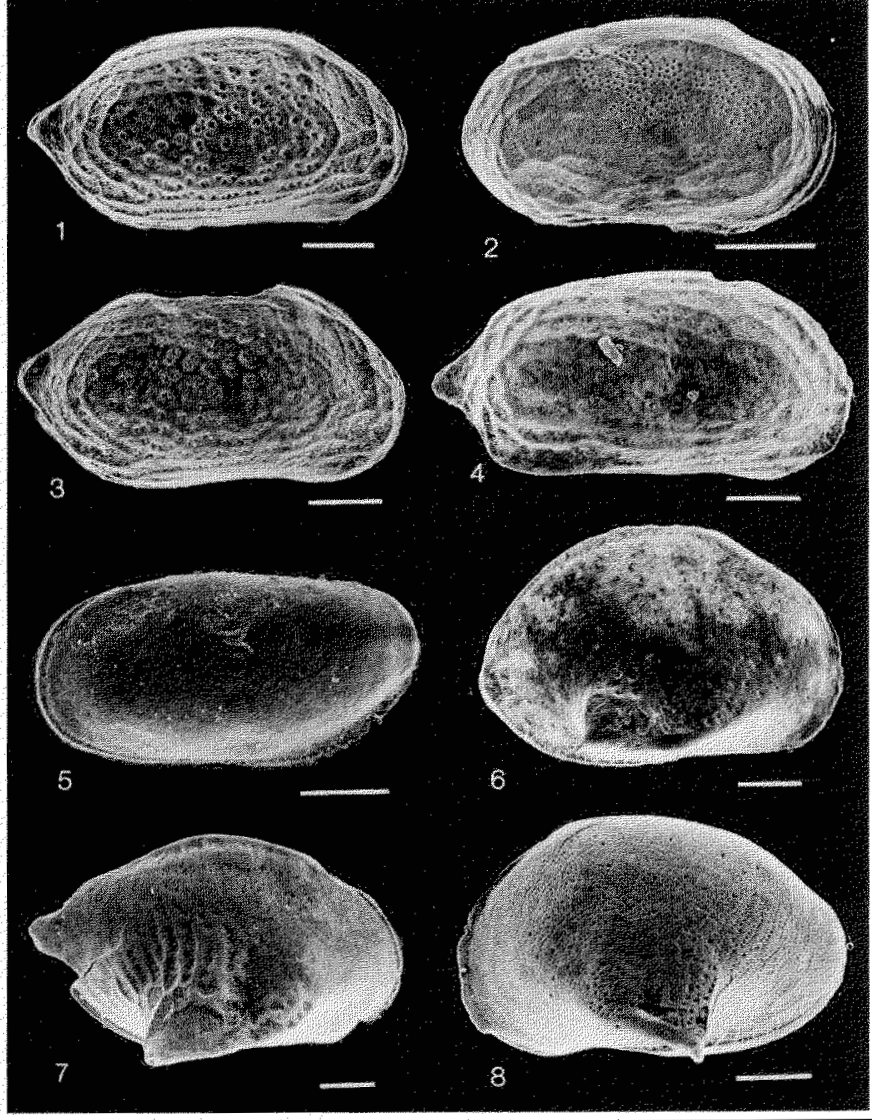

FIG. 14. All figures are scanning electron photomicrographs. White bar equals $100 \mu \mathrm{m}$. 1) Semicytherura concentrica (Brady, Crosskey and Robertson, 1874), sample 81ACr6a, right valve. 2) Semicytherura complanata (Brady, Crosskey and Robertson, 1874), sample 84EB51, right valve. 3) Semicytherura concentrica (Brady, Crosskey and Robertson, 1874), sample 84EB54, right valve. 4) Semicytherura nigrescens (Baird, 1838), sample 90ACr17A5 1/4, right valve. 5) Elofsonia cf. E. pusilla, sample 84EB51, left valve. 6) Cytheropteron arcuatum Brady, Crosskey and Robertson, 1874, sample 81ACr6a, right valve. 7) Cytheropteron paralatissimum Swain, 1963 sample 83EB88, right valve. 8) Cytheropteron aff. C. arcuatum Brady, Crosskey and Robertson, 1874, sample 83EB88, left valve.

localities of the North Atlantic and North Pacific, and the two forms illustrated herein fit within that concept of the species, which includes considerable intraspecific variation in ornamentation, ranging from reticulate (Fig. 9-4) to pitted and reticulate (Fig. 9-6).

Distribution: Marine sublittoral, ranging to $75 \mathrm{~m}$. Most abundant in the Arctic; in Britain, confined to Scotland and eastern England.

Family HEMICYTHERIDAE Puri, 1953

Subfamily HEMICYTHERINAE Puri, 1953

Tribe HEMICYTHERINI Puri, 1953

Genus HEMICYTHERE Sars, 1925

Type species: Cythereis villosa Sars, 1866.

Hemicythere villosa (Sars, 1866)

Figure 10-4

Cythereis villosa Sars, 1866:42.

Cythere villosa (Sars) Brady, 1868:411, Pl. 29, Figs. 28-32 .

Hemicythere villosa (Sars) Sars, 1925:182, Pl. 84.

Hemicythere villosa (Sars) Athersuch and Whittaker, 1981:27-32. 


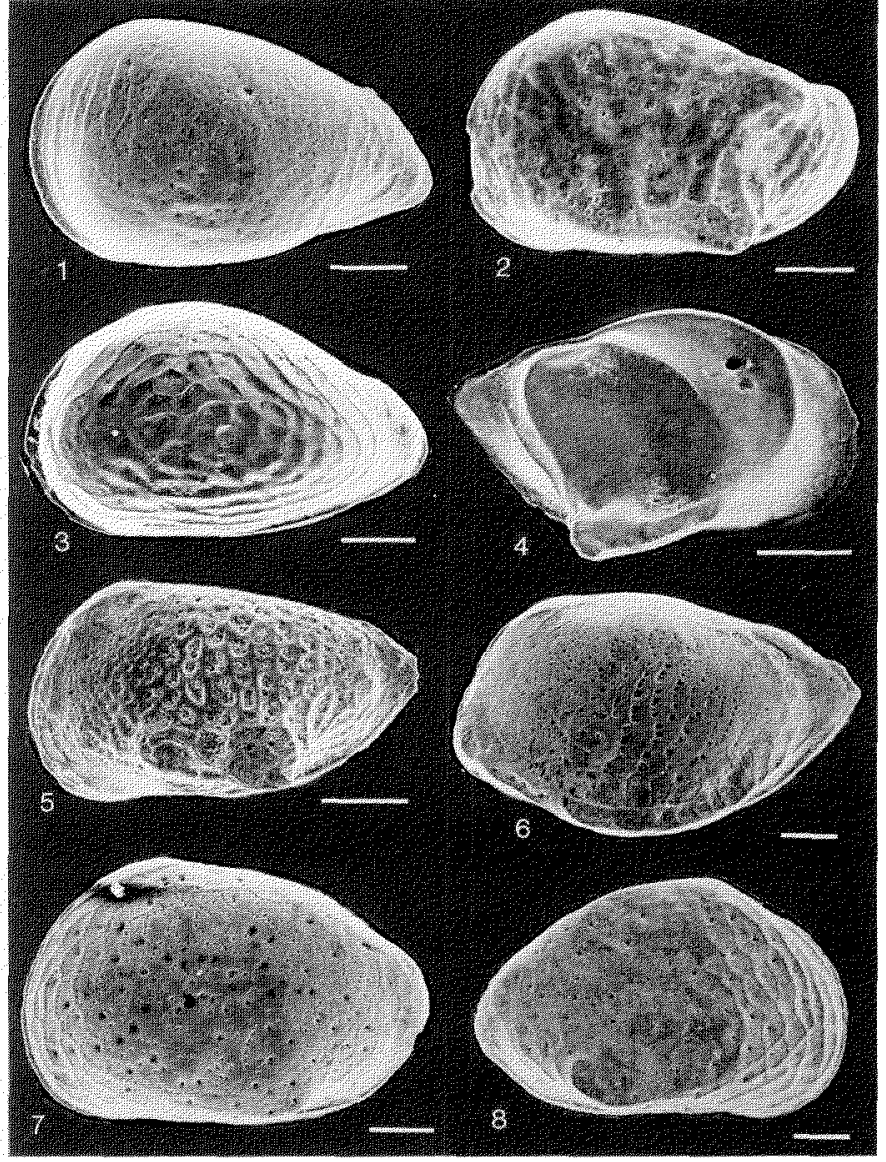

FIG. 15. All figures are scanning electron photomicrographs. White bar equals $100 \mu \mathrm{m}$. 1) Cytheropteron simplex Whatley and Masson, 1979, sample 83EB88, left valve. 2) Cytheropteron elaeni Cronin, 1988, sample 81ACr6a, left valve. 3) Cytheropteron pseudomontrosiense Whatley and Masson, 1979, sample 81ACr6a, left valve. 4) Cytheropteron biconvexum Whatley and Masson, 1979, sample 83EB88, right valve. 5) Cytheropteron sedovi Lev, 1979, sample 83EB54, left valve. 6) Cytheropteron carteri $n$. sp., sample 83EB88, holotype, USNM 408620, left valve. 7) Cytheropteron sp. $B$, sample 90ACr17A5 1/4, left valve. 8) Cytheropteron $\mathrm{sp} . B$ (cf. Cytheropteron sp. 3 of Brouwers et al,, 1991), sample 90ACr19A1, right valve.

Comments: The specimens recovered represent the only occurrence in Alaska of Hemicythere. The species is found at localities $90 \mathrm{ACr} 17$ and $90 \mathrm{ACr} 19 \mathrm{a}$, both Colvillian in age based on amino acid racemization ratios (L.D. Carter, written comm. 1991). Hemicythere villosa is a well-understood taxon that occurs today associated with littoral to shallow sublittoral algae and sediment, being widespread around the coasts of Britain and northwest Europe (Athersuch et al., 1989). Elofson (1941) commonly found the species in the Laminaria zone. Hemicythere villosa is known to tolerate temperatures ranging from $0^{\circ}$ to $22^{\circ} \mathrm{C}$ and is very euryhaline, with a lower salinity limit of $10 \%$. Hazel (1970) identified the species as occurring in mild temperate to subfrigid marine climates, with a temperature range of $<0^{\circ}$ to $>15^{\circ} \mathrm{C}$.

Family CYTHERURIDAE Sars, 1866

Subfamily CYTHEROPTERINAE Hanai, 1957

Genus CYTHEROPTERON Sars, 1866

Type species: Cythere latissima Norman, 1865. Cytheropteron carteri new species

Figure 15-6
Diagnosis: A species of Cytheropteron characterized by a large arcuate ventral ridge that overhangs the margin.

Description: In lateral view, left valve is subtriangular in shape. Dorsal margin is broadly arched; anterior margin with the greatest extent ventral of mid-margin; ventral margin obscured; posterior margin with a pronounced, sharp, narrow caudal process. Dorsal and ventral margins converge markedly toward the posterior. Greatest length through caudal process; greatest height through anterior hinge element.

Valve surface dominated by a smoothly curved ventral ridge that overhangs the entire margin. Weak reticulation is developed along the ventral ridge and anterior and posterior margins. Four vertical rows of rounded pits dominate the middle of the valve. Anterior and posterior marginal areas with scattered fine pits, occurring between the reticulation ridges,

Material: 9 valves.

Etymology: After L.D. Carter, U.S. Geological Survey, Anchorage, who first identified the Kalikpik River locality.

Occurrence: Samples 83EB187, 85ACr229, 90ACr17A5, 83EB88; pre-Colvillian, Colvillian.

Comparisons: Cytheropteron carteri differs from C. ?subcircinatum Sars of Whatley and Masson, 1979, by the shape of ventral ala and anterior margin and the presence of vertically arranged ornament pits.

Subfamily CYTHERURINAE Hanai, 1957 Genus HOWEINA Hanai, 1957

Type species: Howeina camptocytheroidea Hanai, 1957 Howeina colvillensis new species

\section{Figure 13-8}

Diagnosis: A species of Howeina characterized by scalloped reticulation along the ventral and anterior margins and elongate ellipsoidal pits in the dorsal and median valve areas.

Description: In lateral view, right valve is subtriangular to subquadrate in shape. Dorsal margin is broadly arched; anterior margin with an oblique dorsal part and a smoothly rounded ventral part; ventral margin straight to broadly concave; posterior margin with a short, wide caudal process. Greatest length mid-valve; greatest height through middle of valve. No cardinal angles.

Ornament consists of reticulation and pitting. Reticulation consists of scalloped ridges that occur along the anterior and ventral margins. Dorsal and posterior margins with several fine ridges that trend subparallel to the margin. Posteroventral corner with an arcuate ridge that nearly overhangs the margin and terminates at the posterior as a spinose feature. Posteromedian valve covered with scattered narrow, shallow, ellipsoidal pits.

Material: 22 valves.

Etymology: After the Colville River, North Slope, Alaska.

Occurrence: Sample 90ACr17A5; Colvillian.

Comparisons: Howeina colvillensis differs from $H$. camptocytheroidea Hanai, 1957, by its more scalloped anterior ornament, presence of elongate rather than rounded median ornament pits, and arrangement of ornament pits along the dorsal margin and medial sulcus. 


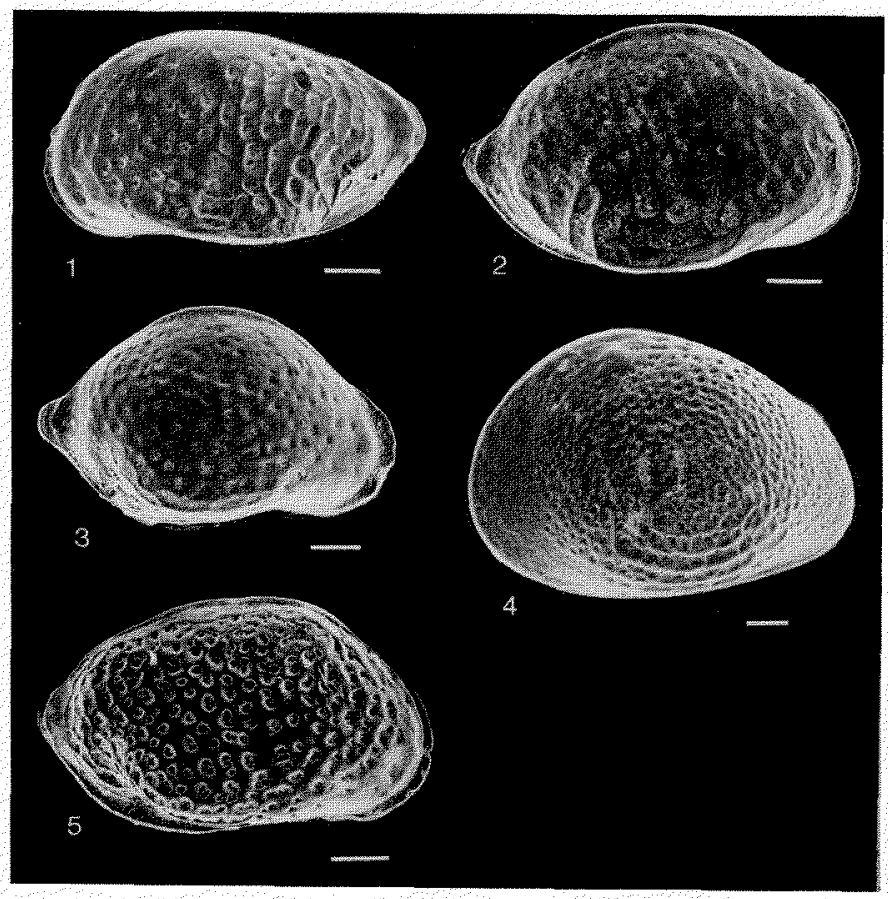

FIG. 16. All figures are scanning electron photomicrographs. White bar equals $100 \mu \mathrm{m}$. 1) Cytheropteron dimlingtonensis Neale and Howe, 1973, sample 83EB187, left valve. 2) Cytheropteron dimlingtonensis Neale and Howe, 1973, sample 84EB60, right valve. 3) Cytheropteron inflatum Brady, Crosskey and Robertson, 1874, sample 84EB51, right valve. 4) Cytheropteron sp. C, sample 84EB68, left valve. 5) Cytheropteron aff. C. latissimum (Norman, 1865), sample 83EB187, right valve.

\section{Family BYTHOCYTHERIDAE Sars, 1866}

Genus BYTHOCYTHERE Sars, 1866

Type species: Bythocythere turgida Sars, 1866.

Bythocythere sp. A

Figure 12-2

Cytheropteron sp. B McDougall et al., 1986: Pl. 11, Figs. 4, 6 .

Comments: This taxon represents a new species of Bythocythere, but I do not have sufficient material to adequately describe it. It is conspecific with Cytheropteron sp. $B$ of McDougall et al. (1986) from Flandrian deposits in a borehole at Prudhoe Bay, Alaska.

Occurrence: $82 \mathrm{ACr} 23$; Bigbendian. Holocene.

\section{ACKNOWLEDGEMENTS}

I am grateful to L. David Carter, U.S. Geological Survey, Anchorage, David M. Hopkins, University of Alaska, Fairbanks, and Julie Brigham-Grette, University of Massachusetts, Amherst, who identified and collected many of the upper Pliocene localities of the Gubik Formation that are summarized here. David McNeil, Geological Survey of Canada, Calgary, has discussed his ideas on the benthic foraminifer assemblages from the Sagavanirktok and Gubik formations and the relationship to Neogene foraminifer assemblages from Canadian high-latitude outcrops and wells. John Matthews and John Fyles, Geological Survey of Canada, Ottawa, have generously provided me with information from their 1990 field season at Ellesmere and Meighen Islands, and Louie Marincovich, Jr., U.S. Geological Survey, Menlo Park, discussed the oldest record of co-occurrence of Pacific and Atlantic mollusks in the Canadian Arctic. John Whittaker (British Museum Natural History), David Horne (Thames Polytechnic, London), David
Penney (Aarhus University, Denmark), Q.A. Siddiqui (St. Mary's University, Halifax), and W.M. Briggs, Jr. (INSTAAR, Boulder) have been very accommodating in sharing unpublished distributional information on ostracodes from the North Atlantic and Canadian Arctic. I thank Darrell Kaufman, Louie Marincovich, Jr., W.M. Briggs, Jr., L. David Carter, and T.M. Cronin for reviewing the manuscript. This paper is a product of the U.S. Geological Survey Global Climate Change PRISM project.

\section{REFERENCES}

AGER, T.A., EDWARDS, L.E., and OFTEDAHL, O. 1985. Eocene palynomorphs from the Franklin Bluffs, Arctic Slope, northeast Alaska. American Association of Stratigraphic Palynologists. Program and Abstracts. Annual Meeting. 7.

ARTHUR, M.A. 1979. Paleoceanographic events - recognition, resolution and reconsideration. Review of Geophysics and Space Physics 17:1474-1494.

ATHERSUCH, J., and WHITTAKER, J.E. 1981. On Hemicythere villosa (Sars). Stereo-Atlas of Ostracod Shells 8(1):27-32.

ATHERSUCH, J., HORNE, D.J., and WHITTAKER, J.E. 1989. Marine and brackish water Ostracods (Superfamilies Cypridacea and Cytheracea). In: Kermack, D.M., and Barnes, R.S.K., eds. Synopses of the British fauna. New Series. The Linnean Society of London 43:1-343.

BERGGREN, W.A., and HOLLISTER, G. 1974. Paleogeography, paleobiology, and history of circulation in the Atlantic Ocean. In: Hay, W.W., ed. Studies in paleoceanography. Society of Economic Paleontologists and Mineralogists. Special Publication 20:126-186.

BIRD, K.G., and MOLENAAR, C.M. 1987. Stratigraphy. In: Bird, K.G., and Magoon, L.P., eds. Petroleum geology of the northern part of the Arctic National Wildlife Refuge, northeastern Alaska. U.S. Geological Survey Bulletin 1778:37-59.

BRADY, G.S. 1868. A monograph of the recent British Ostracoda. Transactions of the Linnean Society of London 26(2):353-495.

BRIGHAM-GRETTE, J., and CARTER, L.D. 1992. Pliocene and early Pleistocene marine transgressions of northern Alaska: Circumarctic correlations. Arctic 45(1):74-89.

BROUWERS, E.M. 1983. Occurrence and distribution chart of ostracodes from the northeastern Gulf of Alaska. U.S. Geological Survey Miscellaneous Field Investigations Map MF-1518.

. 1987. On Pterygocythereis vannieuwenhuisei Brouwers sp. nov. Stereo-Atlas of Ostracod Shells 14(1):17-20.

1990. Systematic paleontology of Quaternary ostracode assemblages from the Gulf of Alaska, Part I: Families Cytherellidae, Bairdiidae, Cytheridae, Leptocytheridae, Limnocytheridae, Eucytheridae, Krithidae, Cushmanideidae. U.S. Geological Survey Professional Paper 1510:1-43.

BROUWERS, E.M., and MARINCOVICH, L., Jr. 1988. Ostracode and molluscan assemblages from the Late Neogene Nuwok Member of the Sagavanirktok Formation, North Slope. In: Galloway, J.P., and Hamilton, T.D., eds. Geologic studies in Alaska by the U.S. Geological Survey during 1987. U.S. Geological Survey Circular 1016:24-26.

BROUWERS, E.M., JORGENSEN, N.O., and CRONIN, T.M. 1991. Climatic significance of the ostracode fauna from the Pliocene Kap Kobenhavn Formation, north Greenland. Micropaleontology 37(3):245-267.

CARTER, L.D., and GALLOWAY, J.P. 1985. Engineering-geologic maps of northern Alaska, Harrison Bay quadrangle. U.S. Geological Survey Open-File Report 85-256. 47 p., 2 map sheets (scale 1:250 000).

CARTER, L.D., and HILLHOUSE, J.W. 1991. Age of the late Cenozoic Bigbendian marine transgression of the Alaskan Arctic Coastal Plain: Significance for permafrost history and paleoclimate. In: Bradley, D.C., and Ford, A.B., eds. Geologic Studies in Alaska by the U.S. Geological Survey, 1990. U.S. Geological Survey Bulletin.

CARTER, L.D., BRIGHAM-GRETTE, J.K., and HOPKINS, D.M. 1986a. Late Cenozoic marine transgressions of the Alaskan Arctic Coastal Plain. In: Heginbottom, J.A., and Vincent, J.-S., eds. Correlation of Quaternary deposits and events around the Beaufort Sea. Geological Survey of Canada, Open-File Report 1237:21-26.

CARTER, L.D., BRIGHAM-GRETTE, J., MARINCOVICH, L., PEASE, V.L., and HILLHOUSE, J.W. 1986b. Late Cenozoic Arctic Ocean sea ice and terrestrial paleoclimate. Geology 14:675-678. 
CLARK, D.L. 1990. Arctic Ocean ice cover; Geologic history and climatic significance. In: Grantz, A., Johnson, L., and Sweeney, J.F., eds. The Arctic Ocean region. Geological Society of America. The Geology of North America. L:53-62.

CRONIN, T.M., and DOWSETT, H.J. 1990. A quantitative micropaleontologic record for shallow marine paleoclimatology: Application to Pliocene deposits of the western North Atlantic Ocean. Marine Micropaleontology 16:117-147.

CRONIN, T.M., BRIGGS, W.M., Jr., BROUWERS, E.M., WHATLEY, R.C., WOOD, A., and COTTON, M.A. 1991. Modern arctic Podocopid ostracode data base. U.S. Geological Survey Open File Report 91-385:1-51.

DETTERMAN, R.L., REISER, H.N., BROSGE', W.P., and DUTRO, J.T. 1975. Post-Carboniferous stratigraphy, northeastern Alaska. U.S. Geological Survey Professional Paper 886:1-46.

DINTER, D., CARTER, L.D., and BRIGHAM-GRETTE, J. 1990. Late Cenozoic geologic evolution of the Alaskan North Slope and adjacent continental shelves. In: Grantz, A., Johnson, L., and Sweeney, J.F., eds. The Arctic Ocean region. Geological Society of America. Decade of North American Geology L:459-490.

DURHAM, J.W., and MacNEIL, F.S. 1967. Cenozoic migrations of marine invertebrates through the Bering Strait region. In: Hopkins, D.M., ed. The Bering Land Bridge. Stanford: Stanford University Press. 326-349.

EINARSSON, T., and ALBERTSSON, K.J. 1988. The glacial history of Iceland during the past three million years. Philosophical Transactions of the Royal Society of London B318:637-644.

ELOFSON, O. 1941. Marine Ostracoda of Sweden. Zoologiska Bidrag fran Uppsala. 1-286. Translated from German, Israel Program for Scientific Translations, Jerusalem, 1969.

FOUCH, T.D., BROUWERS, E.M., McNEIL, D.H., MARINCOVICH, L., Jr., BIRD, K.J., and RIECK, H. 1990. New information on the Nuwok Member of Sagavanirktok Formation; implications for petroleum geology of the North Slope and Beaufort Sea; evidence from Carter Creek, Arctic National Wildlife Refuge (ANWR), Alaska. In: Carter, L.M.H., ed. USGS Research on Energy Resources. 1990. Program and Abstracts. Sixth V.E. McKelvey Forum on Mineral and Energy Resources. U.S. Geological Survey Circular 1060:30-31.

FYLES, J.G., MARINCOVICH, L., Jr., MATTHEWS, J.V., Jr., and BARENDREGT, R. 1991. Unique mollusc find in the Beaufort Formation (Pliocene) on Meighen Island, arctic Canada. Current Research. Part B. Geological Survey of Canada. Paper 91-B:105-112.

GLADENKOV, Y.B. 1981. Marine Plio-Pleistocene of Iceland and problems of its correlation. Quaternary Research 15:18-23.

GLADENKOV, Y.B., BARINOV, K.B., BASILIAN, A.E., and CRONIN, T.M. 1991. Stratigraphy and paleoceanography of Pliocene deposits of Karaginsky Island, eastern Kamchatka, U.S.S.R. Quaternary Science Reviews 10:239-245.

GLADENKOV, Y.B., NORTON, P., and SPAINK, G. 1980. Upper Cenozoic of Iceland. U.S.S.R. Academy of Sciences. Transactions $345: 1-115$.

GRANTZ, A., DINTER, D.A., HILL, E.R., MAY, S.D., McMULLIN, R.H., PHILLIPS, R.L., and REIMNITZ, E. 1982. Geologic framework, hydrocarbon potential, and environmental conditions for exploration and development of proposed oil and gas lease sale 87 in the Beaufort and northeast Chukchi seas. U.S. Geological Survey. Open File Report 82-482:1-71

GRANTZ, A., MAY, S.D., and HART, P.E. 1990. Geology of the arctic continental margin of Alaska. In: Grantz, A., Johnson, L., and Sweeney, J.F., eds. The Arctic Ocean region. Geological Society of America. The Geology of North America L:257-288.

HAZEL, J.E. 1970. Atlantic continental shelf and slope of the United States - Ostracode zoogeography in the southern Nova Scotian and northern Virginian faunal provinces. U.S. Geological Survey Professional Paper 529E:E1-E21.

1977. Use of certain multivariate and other techniques in assemblage zonal biostratigraphy: Examples utilizing Cambrian, Cretaceous, and Tertiary benthic invertebrates. In: Kauffman, E.G., and Hazel, J.E., eds. Concepts and methods of biostratigraphy. Stroudsburg, Pennsylvania: Dowden, Hutchinson and Ross, Inc. 187-212.

HERMAN, Y., and HOPKINS, D.M. 1980. Arctic Oceanic climate in Late Cenozoic time. Science 209:557-562.

HODELL, D.S., WILLIAMS, D.F., and KENNETT, J.P. 1985. Late Pliocene reorganization of deep vertical water-mass structure in the western South Atlantic: Faunal and isotopic evidence. Bulletin of the Geological Society of America. 96:495-503.

HOPKINS, D.M. 1967. Quaternary marine transgressions in Alaska. In: Hopkins, D.M., ed. The Bering Land Bridge. Stanford: Stanford University Press. 47-90.

1972. The paleogeography and climatic history of Beringia during the past 250000 years. Quaternary Research 3:520-540.

HORNE, D.J. 1983. On Robertsonites tuberculatus (Sars). Stereo-Atlas of Ostracod Shells 10(1):39-52.

ISHIZAKI, K., and MATOBA, T. 1985. Akita, early Pleistocene cold, shallow water Ostracoda. Guidebook of Excursions. Excursion 5. 9th International Symposium on Ostracoda, Shizuoka University. 1-12.

JANSEN, E., and SJOHOLM, J. 1991. Reconstruction of glaciation over the past 6 Myr from ice-borne deposits in the Norwegian Sea. Nature 349:600-603.

JONES, D.S., and HASSON, P.F. 1985. History and development of the marine invertebrate faunas separated by the Central American Isthmus. In: Stehli, F.G., and Webb, S.D., eds. Great American Interchange. New York: Plenum Press. 325-355.

KAUFMAN, D.S., FARMER, G.L., MILLER, G.H., CARTER, L.D., and BRIGHAM-GRETTE, J. 1990. Strontium isotopic dating of upper Cenozoic marine deposits, northwestern Alaska. In: Gosnell, L.B., and Poore, R.Z., eds. Pliocene climates: Scenario for global warming. Abstracts from USGS workshop, Denver, 23-25 October 1989. U.S. Geological Survey Open File Report 90-64:17-21.

KEIGWIN, L.D. 1978. Pliocene closing of the Isthmus of Panama, based on biostratigraphic evidence from nearby Pacific Ocean and Caribbean Sea cores. Geology 6:630-634.

1982. Neogene planktonic foraminifers from deep sea drilling project sites 502 and 503. Initial Reports. Deep Sea Drilling Project 68:269-288.

KENNETT, J.P. 1982. Marine geology. Englewood Cliffs: Prentice-Hall. $1-813$.

LYLE, W.M., PALMER, I.F., Jr., BOLM, J.G., and MAXEY, L.R. 1980. Post-Early Triassic formations of northeastern Alaska and their petroleum reservoir and source-rock potential. Alaska Department of Natural Resources, Division of Geological and Geophysical Survey. Geological Report 76:1-100.

MANKINEN, E.A., and DALRYMPLE, G.B. 1979. Revised geomagnetic polarity time scale for the interval 0-5 m.y. BP. Journal of Geophysical Research 84(B2):615-626.

MARINCOVICH, L., Jr., and POWELL, C.L. 1991. Comment and reply on "High-latitude application of ${ }^{87} \mathrm{Sr} /{ }^{86} \mathrm{Sr}$ : Correlation of Nuwok beds on North Slope, Alaska, to standard chronostratigraphy." Geology 5(5):537-539.

MARINCOVICH, L., Jr., BROUWERS, E.M., HOPKINS, D.M., and McKENNA, M.C. 1990. Late Mesozoic and Cenozoic paleogeographic and paleoclimatic history of the Arctic Ocean Basin, based on shallowwater marine faunas and terrestrial invertebrates. In: Grantz, A., Johnson, L., and Sweeney, J.F., eds. The Arctic Ocean region. Geological Society of America, Decade of North American Geology L:403-426.

McDOUGALL, K., BROUWERS, E., and SMITH, P. 1986. Micropaleontology and sedimentology of the PB borehole series, Prudhoe Bay, Alaska. U.S. Geological Survey Bulletin 1598:1-62.

McNEIL, D.H., and MILLER, K.G. 1990. High-latitude application of ${ }^{87} \mathrm{Sr} /{ }^{86} \mathrm{Sr}$ : Correlation of Nuwok beds on North Slope, Alaska, to standard Oligocene chronostratigraphy. Geology 18(5):415-418.

MOLENAAR, C.M., BIRD, K.G., and KIRK, A.R. 1987. Cretaceous and Tertiary stratigraphy of northeastern Alaska. In: Tailleur, I.L., and Weimer, P., eds. North Slope geology. Bakersfield, California: Pacific Section Society of Economic Paleontologists and Mineralogists. 513-528.

MORRIS, R.H. 1957. Reconnaissance study of the Marsh anticline, northern Alaska. U.S. Geological Survey Open File Report 57-76:1-6.

NEALE, J.W., and HOWE, H.V. 1975. The marine Ostracoda of Russian Harbor, Novaya Zemlya and other high latitude faunas. In: Swain, F.M., ed. Biology and paleobiology of Ostracoda. American Paleontological Bulletins 65(282):381-431.

NELSON, R.E., and CARTER, L.D. 1991. Preliminary interpretation of vegetation and paleoclimate in northern Alaska during the Late Pliocene Colvillian marine transgression. In: Bradley, D.C., and Ford, A.B., eds. Geologic studies in Alaska by the U.S. Geological Survey, 1990. U.S. Geological Survey Bulletin. 
OVERPECK, J.T , WEBB, T., and PRENTICE, I.C. 1985. Quantitative interpretation of fossil pollen spectra: Dissimilarity coefficients and the method of modern analogs. Quaternary Research 23:87-108.

PENNEY, D.N. 1990. Quaternary ostracod chronology of the central North Sea: The record from BH 81/29. Courier Forschungs-Institut Senckenberg 123:97-109.

RAYMO, M.E., RIND, W.F., and RUDDIMAN, W.F. 1990. Climatic effects of reduced arctic sea ice limits in the GISS II general circulation model. Paleoceanography 5(3):367-382.

RAYMO, M.E., RUDDIMAN, W.F., BACKMAN, J., CLEMENT, B.M., and MARTINSON, D.G. 1989. Late Pliocene variation in Northern Hemisphere ice sheets and North Atlantic deep water circulation. Paleoceanography 4(4):413-446.

RAYMO, M.E., RUDDIMAN, W.F., and FROELICH, P.N. 1988 Influence of late Cenozoic mountain building on ocean geochemical cycles. Geology 16:649-653.

REISER, H.N., BROSGE', W.P., DUTRO, J.T., Jr., and DETTERMAN, R.L. 1971. Preliminary geologic map, Mt. Michelson quadrangle, Alaska. U.S. Geological Survey Open File Report.

REPENNING, C.A., and BROUWERS, E.M. 1992. Late Pliocene-Early Pleistocene ecologic changes in the Arctic Ocean Borderland. U.S Geological Survey Bulletin 2036:1-37.

REPENNING, C.A., BROUWERS, E.M., CARTER, L.D., MARINCOVICH, L., Jr., and AGER, T.A. 1987. The Beringian ancestry of Phenacomys (Rodentia: Cricetidae) and the beginning of the modern Arctic Ocean Borderland biota. U.S. Geological Survey Bulletin 1687:1-31.

RUDDIMAN, W.F., and KUTZBACH, J.E. 1989. Forcing of late Cenozoic northern hemisphere climate by plateau uplift in southeast Asia and the American Southwest. Journal of Geophysical Research 94(18):409-418.

SARS, G.O. 1866. Oversight af Norges Marine Ostracoder. Forhandlinger I Videnskabs-Selskabet I Christiania. 1-130. 1925. An account of the Crustacea of Norway with short descriptions and figures of all the species. Ostracoda 9(5-12):73-208. SHACKLETON, N.J., BACKMAN, J., ZIMMERMAN, H., KENT, D.V., HALL, M.A., ROBERTS, D.G., SCHNITKER, D., BALDAUF, J., DESPARAIRIES, A., HOMRIGHAUSEN, R., HUDDLESTUN, P., KEENE, J.B., KALTENBACK, A.J., KRUMSIEK, K.A.O., MORTON, A.C., MURRAY, J.W., and WESTBERG-SMITH, J. 1984. Oxygen isotope calibration of the onset of ice-rafting and history of glaciation in the North Atlantic region. Nature 307:620-623.

SIKES, E.L., KEIGWIN, L.D., and CURRY, W.B. 1991. Pliocene paleoceanography: Circulation and oceanographic changes associated with the 2.4 MA glacial event. Paleoceanography 6(2):245-257.

SWAIN, F.M. 1963. Pleistocene Ostracoda from the Gubik Formation, Arctic Coastal Plain, Alaska. Journal of Paleontology 37(4):798-834.

WHATLEY, R.C., and MASSON, D.G. 1979. The ostracod genus Cytheropteron from the Quaternary and Recent of Great Britain. Revista Español de Micropaleontologia 11(2):223-277. 